\title{
EGY NAGYVÁROS HELYZETE AZ INFORMÁCIÓS TÁRSADALOMBAN
}

\author{
(The Position of a Municipality \\ in the Information Society)
}

\section{BARSI BOGLÁRKA - CSIZMADIA ZOLTÁN}

Kulcsszavak:

megyei jogú városok információs társadalom ellátottság

A napjainkban zajló fejlödési folyamatok fó motorja a információs technológia, amely az elkövetke=ö évtizedekben a legnagyobb ipari szektorrá válhat. Ez a folyamat azonban óriási társadalmi kihatással jár együtt Magyarországon is, ahol napjainkban éljük át az információs társadalomba vezetõ átmenetet. A magyar városhálözat gerincét alkotó megyei jogú városok között éles verseny folyik új befektetök megnyeréséért, ủj igazgatási és adminisztrativ funkciók megszerzéséért. Az információs társadalom új versenyhelyzet elé állítja Magyarországot, igy a városhálózatot is. Ezért is fontos az egyes nagyvárosok helyzetét a többi megyei jogú városhoz viszonyítva megvizsgálni, hogy pontosabb képet nyerhessünk az egyes városok információs tảrsadalomban betöltött szerepérōl.

\section{Bevezetés}

Az információs társadalomról való társadalomtudományi gondolkodás, kutatás az 1990-es évek közepe óta fokozatosan elötérbe került, bár az információs társadalom kifejezés maga is vitatott és új keletü (Élö-Pintér 1999). Más, az információs társadalom fogalomkörébe tartozó jelenségeket vizsgáló terminussal azonban már korábban is találkozhattunk. Ilyen kifejezések például a posztindusztriális társadalom (Bell 1973), a poszt-kapitalista társadalom (Drucker 1993) vagy a tudástársadalom (Stehr 1994).

$\mathrm{Az}$ információs társadalom kifejezés alatt elsősorban az információs és kommunikációs technológia ugrásszerủ fejlődését, és az ehhez kapcsolódó gyártóés szolgáltató-, valamint médiaipar globalizácioját, és az ehhez kötődő folyamatok eredményeként kialakuló új életformát, viselkedést értjük (Fodor 2000).

$\mathrm{Az}$ információs társadalom közelebb hozza egymáshoz a régiókat, országokat és városokat. A konvergens információs és kommunikációs technológiák fejlesztése és bevezetése óriási hatással van a világ minden részén található kưlönböző típusú és méretü szervezeti egységekre. Az információs társadalom sikerének egyik legkritikusabb ilyen egysége a város, amely, akárcsak a többi entitás olyan új kihívásokkal néz szembe, mint a demokrácia új lehetőségei vagy az elektronikus kereskedelem. Az ICT (információ és kommunikáció technológiai) szektor megteremti a hatóságok számára jobb és költség-hatékony szolgáltatások nyújtásának, valamint a demokratikus folyamatok és a regionális gazdasági fejlődés megerösítésének lehetöségét (Telecities... 1998). A fejlesztéshez, továbblépéshez 
Barsi Boglárka - Csizmadia Zoltán: Egy nagyváros helyzete az információs társadalomban.

Tér és Társadalom, 15. 2001. 2. 147-172. p.

azonban elengedhetetlen a jelenlegi helyzet, a kiinduló állapot feltárása, megértése. Magyarországon még kevés olyan kezdeményezés született, mely ezen új kihívásokkal szembesülő települések helyzetét kivánja feltárni. Tanulmányunk egy ilyen úttörő kísérletet kíván bemutatni.

A tanulmány első részében a megyei jogú városok helyzetét vizsgáljuk az információs társadalomban. A távközlési piac, az informatikusképzés, illetve a közoktatás internetes ellátottságának területein próbáltuk meg feltérképezni a megyei jogú városok versenyképességét. A második részben pedig megvizsgáljuk egy konkrét nagyváros felkészültségét az „információs korra”, kiemelten vizsgálva a jelenlegi hiányosságokat is ${ }^{\mathrm{I}}$. Röviden felvázoljuk a helyzetelemzés módszertanát, másrészt részletesen elemezzük a számítógép- és az Internet-hozzáférés györi sajátosságait, illetve bemutatjuk az általunk kialakított két hozzáférői csoport demográfiai és társadalmi jellemzöiben fellelhető eltéréseket. Feltételezésünk szerint a kulturális (iskolai végzettség) és a gazdasági eröforrások (jövedelem, tartós fogyasztási cikkek) mentén jelentkeznek a legjelentősebb eltérések a jelenleg már személyi számitógépet használók és a kimaradtak csoportja között. Így átláthatóbbá válnak a számítástechnikában érintett és a jelenleg még „kizárt” csoportok társadalmi különbségei.

\section{A megyei jogú városok helyzete az információs társadalomban}

A magyar városhálózat gerincét alkotó megyei jogú városok között éles verseny folyik új befektetők megnyeréséért, új igazgatási és adminisztrativ funkciók megszerzéséért. Az információs társadalom íj versenyhelyzet elé állítja Magyarországot, így a városhálózatot is. Ezért is fontos az egyes nagyvárosok helyzetét a többi megyei jogú városhoz viszonyítva megvizsgálni, hogy pontosabb képet nyerhessünk a városok információs társadalomban betöltött szerepéröl.

Az ICT szektor fejlödésének dinamizmusa óriási. 2001-ben a távközlési piac nagyságát 2205 milliárd euróra becsülték. Az Internet-használók száma pedig 10 év alatt több mint százharmincszorosára emelkedett. A hazai infokommunikációs piac mérete az elemzők szerint 2001-ben eléri a 4 milliárd eurót (Nemzetközi... 2001). E rendkívül dinamikusan növekvö ágazat fejlödését tekintve az elkövetkező évtized fontos kérdése az lesz, hogy az információ mindenki számára elérhetö lesz-e, társadalmi és térbeli helyzettől függetlenül, vagy egy újfajta egyenlötlenség kialakulásának leszünk tanúi.

Elemzésünk célja az volt, hogy megpróbáljuk feltárni a megyei jogú városok jelenlegi helyzetét az információs társadalomban, kiemelten kezelve Györ versenyképességét. Munkánk során számos módszertani és statisztikai problémába ütköztünk. Az információs társadalommal kapcsolatos statisztikai tevékenység még az EU országaiban is gyerekcipöben jár - kivételt képeznek talán a skandináv országok -, ezért az adatok korlátozottan álltak rendelkezésre. A statisztikai adatok általában csak 1-2 éves késéssel mutatják a fejlödést, amely ilyen dinamikusan növekvö ágazat esetében hamis képet festhet. Elemzésünk során helyenként mi is 
Barsi Boglárka - Csizmadia Zoltán: Egy nagyváros helyzete az információs társadalomban.

Tér és Társadalom, 15. 2001. 2. 147-172. p.

TÉT XV. évf. 2001 — 2

Egy nagyváros helyzete...

csak a Hírközlési Fófelügyelet 1999-es adatokat tartalmazó statisztikai évkönyvére támaszkodhattunk.

\section{A megyei jogú városok és a távközlési piac}

A távközlési piac mérete az elmúlt tíz évben mintegy harminckétszeresére növekedett. Az 1990-es évek elején a növekedés üteme jellemzően 40-60\% között alakult, de az évtized második felében is folyamatosan $20 \%$ felett maradt. Az utóbbi néhány évben lassult a fejlödés üteme - elsősorban a vezetékes telefonok piacának telítődése miatt -, ám a mobiltelefonok piaca és az Internet térhódítása bizonyos fokig képes volt ezt ellensúlyozni.

A mobiltelefonok elterjedtsége ugrásszerủen megnőtt Magyarországon. 2001-ben az összes magyar háztartás 43\%-a használ mobiltelefont, ez összesen 3,5 millió használatban lévő készüléket jelent. A jövő szempontjából fontos 15-19 éves korosztályban minden második fiatalnak van már mobiltelefonja (Pannon GSM... 2001). Egy háztartásra átlagosan kettőnél több készülék jut. A mobiltelefon rendszer egyelöre nem játszik túl nagy szerepet az adatátvitel és az Internetszolgáltatás területén. Ez elsősorban a magas szolgáltatási díjakkal és a mủszaki korlátokkal magyarázható. A legtöbb felhasználó nagyon lassúnak és körülményesnek találta a WAP használatát, és a külföldi felmérések alapján 70\%-uk nem kívánja használni azt. 2000-ben 9000 körüli mobilos internetezỏt tartottak számon hazánkban. A csekély mértékủ mobilon keresztüli internetezés világtendencia, hiszen a 2000 végén nyilvántartott 700 millió mobil-elöfizetó közül csak 8 millióan használták a WAP szolgáltatást. A döntő változás ezen a téren a GPRS és a WAP után az UMTS rendszerek megjelenésétől várható (melynek révén az adatátvitel sebessége elérhetné 2 Mbps-t is) (Nielsen-Ramsay 2000).

A vezetékes távközlési piac növekedésének fö motorját az ISDN (Integrated Services Digital Network) vonalak bekötési díjai jelentették elsősorban. A vezetékes telefon piacának mennyiségi növekedése ugyanis telítődik. A fejlődési alternatívát ezért a szolgáltatások minőségi fejlesztése jelentheti. Ezt irányozták elö a 2000-ben elindított ISDN kampányok.

A megyei jogú városok közủl Sopron mind a telefon fővonalszám, mind az ISDN készülékek aránya szempontjából is nagyon kedvezỏ helyzetben volt 1999-ben. Emellett Györ esetében is átlag feletti az ISDN vonalak száma. A megyei jogú városok közül Sopron után itt található legnagyobb arányban ez a szélesebb sávú kommunikációt lehetővé tevő megoldás. Kevés az információnk azonban arról, hogy mennyi vonal van a lakosság tulajdonában. Az ISDN vonalak nagy részét valószínúleg vállalatok és intézmények használják, bár a lakossági felmérésünk szerint az otthoni internetezők 30,8\%-a ISDN vonalat használ Győrben. A jövő pedig a gyors elérést, letöltést, adatforgalmat lehetövé tevő rendszerekben van, amely természetesen a költségeket is csökkenti. Az Internet világával, lehetőségeivel megismerkedők a minőségi elérésre törekednek, elengedhetetlen számukra a nagyobb adatátviteli sebesség. 
Barsi Boglárka - Csizmadia Zoltán: Egy nagyváros helyzete az információs társadalomban.

Tér és Társadalom, 15. 2001. 2. 147-172. p.

150 Barsi Boglárka-Csizmadia Zoltán

TÉT XV. évf. 2001

Magyarország az 1999. évhez képest jelentősen fejlödött ISDN ellátottság tekintetében. A vonalak száma 1999-ben 160\%-kal, 2000-ben majd 280\%-kal nótt. Az ISDN vonalak aránya 2000 utolsó negyedévében országosan már elérte a 8,5\%-ot (ugyanebben az időszakban az EU-ban ez a mutató 9\% körüli értéken állt). $\mathrm{Az}$ alacsony kezdeti kiinduló érték ellenére tehát hazánk felzárkózott a nemzetközi értékekhez (Nemzetközi... 2001).

Mivel ma Magyarországon az Internet-felhasználók zöme a bérelt vonal mellett a kapcsolt vonali és ISDN szolgáltatásokat veszi igénybe, az „információs szupersztráda" elérhetősége minden - az ezt megfizetni képes - telefon elöfizetőtől karnyújtásnyira van csupán. Ez ugyanakkor azt is jelenti, hogy a magyar átlagos Web-felhasználó az Internet-szolgáltatók mellett jelentősen függ az általa igénybe vehető telefontársaságok tarifarendszerétől is. A vásárlóerőhöz viszonyítva pedig az Internet-hozzáférés az OECD országai közül Magyarországon és Csehországban a legdrágább.

Az OECD országok körében terjed az ingyenes Internet-szolgáltatók térhódítása is. Azokban az országokban, ahol percdíjas a helyi hivás, az ingyenes Internetszolgáltatók bevételeik egy részét a távközlési szolgáltatók dijai után kapják. Ugyanakkor azokban az országokban, ahol elérhetövé vált az átalánydijas Internet, a felhasználók az előfizetési dịjat felszámító szolgáltatókhoz tértek vissza. $\mathrm{Az}$ is elmondható továbbá, hogy az Internet-hostok száma és a használati dịj kőzött igen erős a korreláció, azaz azokban az országokban a legmagasabb az egy fơre jutó Internet-hostok száma, ahol alacsony az Internet hozzáférési dija (Nemzetközi... 2001).

2001. augusztus 1-jétöl már nem csak a budapestiek élvezhetik az ADSL (Asymmetric Digital Subsciber Line) szélessávú Internet-hozzáférés előnyeit. Jelenleg a győri, zalaegerszegi és székesfehérvári felhasználók is előfizethetnek a szolgáltatásra. A feltöltés, azaz a kifelé irányuló adatforgalom sebessége $384 \mathrm{kbit} / \mathrm{s}$ lehet, internetezés közben pedig a telefon és faxvonalak szabadok maradnak, és az internetezést telefonforgalmi díj sem drágítja. Az ADSL Internet-hozzáférésre alkalmas városok köre a jövőben tovább fog bővülni, amint ezt az egyes városokban a telefonhálózat lehetővé teszi.

Míg a távkőzlési piac egyes óriásai esetleg a fogyasztónak kedvezőbb megoldásokat is kínálhatnak majd a közeljövőben élénkülö távkőzlési versenyben, arra vélhetően nem lehet majd számítani, hogy egyes városok érdekeinek, igényeinek megfelelő egyedi megoldások kialakításában részt vegyenek. A fejlesztésekbe könnyebben bevonható, kompromisszumkész partnerként ugyanakkor várhatóan jó eséllyel számíthatnak majd az egyes városok az ugyan kisebb fajsúlyú, de helyi székhelyü, illetve az adott régióra koncentráló szolgáltatókra (I. ábra). Elemzésünk során a Budapesti Hírközlési Felügyelet által közzétett közcélú, nem koncesszióköteles távközlési szolgáltatást nyújtó vállalkozások jegyzékét használtuk fel. A szolgáltatókat szolgáltatási területük alapján szétbontottuk, és az egyes megyei jogú városokhoz rendeltük, majd a vállalkozások számát összesítettük. Noha egyértelmü rangsor nem állapítható meg, 
Barsi Boglárka - Csizmadia Zoltán: Egy nagyváros helyzete az információs társadalomban. Tér és Társadalom, 15. 2001. 2. 147-172. p.

illetve állitható fel a városok között, de a jelen lévő helyi szolgáltatók mindegyike egy-egy potenciális partnerként fogható fel a városi hálózati fejlesztéseknél. Míg az Internet-hozzáférés és integrált távközlési szolgáltatók esetében közel azonos a helyi és regionális engedélyek száma az országosokéval, megfigyelhetỏ, hogy a vezetékes müsor-jelelosztásban nincs országos szolgáltató.

\section{1. ÁBRA}

Helyi és regionális, közcélú, nem koncesszióköteles távközlési szolgáltatók jelenléte (db)

(Local and regional public telecommunication service providers, without concession obligation)

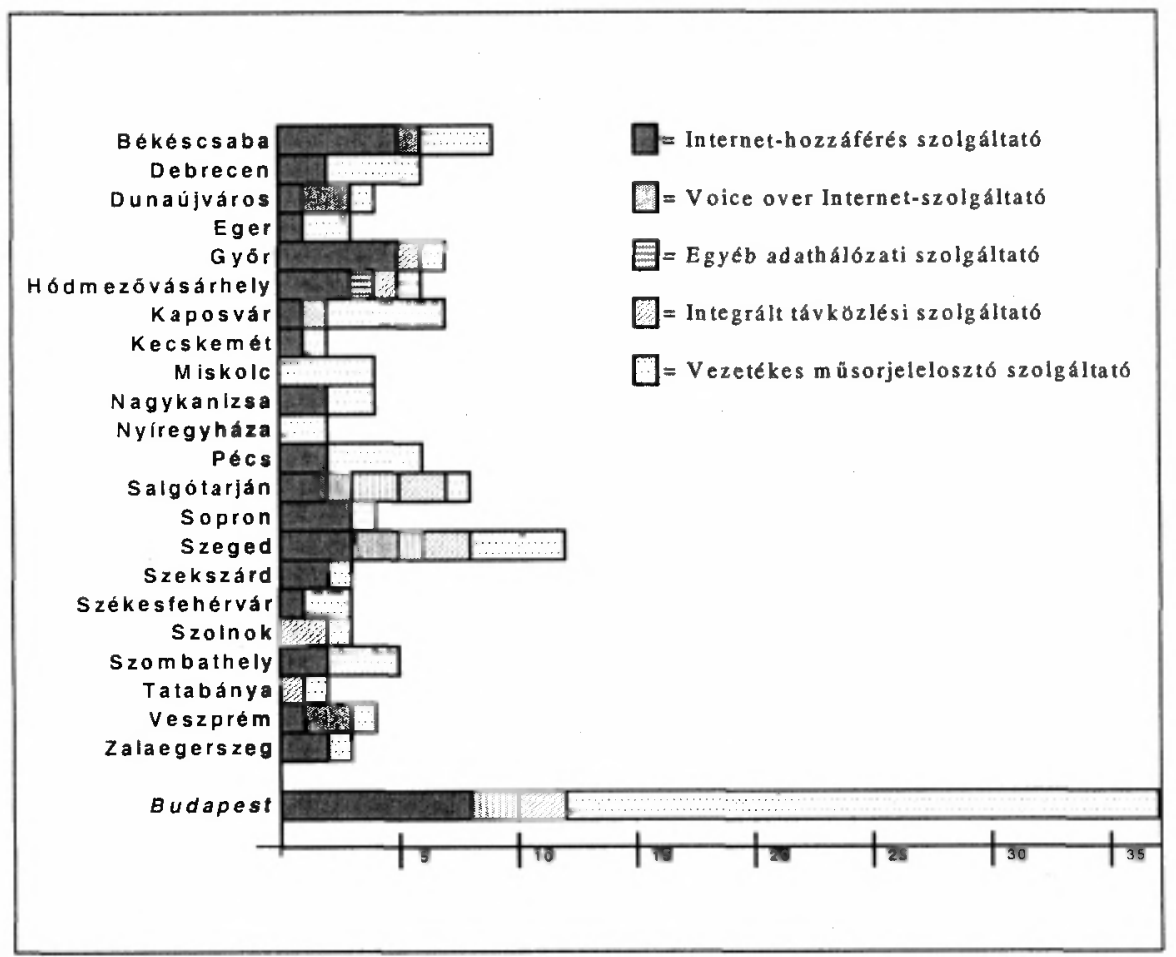

Forrás: Budapest Hírközlési Felügyelet (2001) alapjăn saját szerkesztés².

$\mathrm{Az}$ Internet-szolgáltatók előfordulását, elérhetőségét megvizsgáltuk más forrásra támaszkodva is (www.isz.hu). A szolgáltatókat tartalmazó weboldalon lehetőség volt azok területi bontására is. A megyei jogú városok nevét megadva, megkaptuk az adott városban elérhető, azaz Internet-szolgáltatást nyújtó vállalkozások listáját, ezeket összesitettük. A kapott lista részletezésével kiválogattuk az adott városban bejegyzett szolgáltatókat is. Ez alapján elmondhatjuk, hogy Gyôr mind az Internetszolgáltatók székhelye, mind az elérhetõ Internet-szolgáltatók száma szerint kiemelkedö helyzetben van (2. ábra). A megyei jogú városok közül Győrben található a legtöbb bejegyzett, azaz györi székhelyủ szolgáltató (6 db), és itt áll rendelkezésre a legtöbb szolgáltató $(10 \mathrm{db})$. Györt közvetlenül Székesfehérvár 
Barsi Boglárka - Csizmadia Zoltán: Egy nagyváros helyzete az információs társadalomban. Tér és Társadalom, 15. 2001. 2. 147-172. p.

követi a rangsorban. Ez azt jelenti, hogy a lakosság szabadon választhat a szolgáltatók kỏzül, azok éles versenyhelyzetben vannak. A szolgáltatók nagy száma azonban nem annyira a lakossági Internet használattal magyarázható, hanem a gazdasági tevékenység dinamizmusával lehet inkább összefüggésben. Nem véletlen, hogy Györ mellett Székesfehérvár van még elönyös pozícióban. E két város a városok versenyképességi rangsorában is az elsó két helyet foglalja el. Ha a városok nagyságát is figyelembe veszzük, akkor kiegyenlítettebb mezőnyt kapunk. Hasonlóan elmondhatjuk, hogy a szerverek területi eloszlása is a gazdasági aktivitással mutat kapcsolatot. Erre utal az a tény is, hogy a bejegyzett szervergépek több mint $75 \%$-a valamilyen üzleti tevékenységhez kötödik, nagyobb részt a szolgáltatási és a kereskedelmi szférához. Az Internet-szolgáltatók száma és a penetráció között persze nehéz párhuzamot vonni. A nemzetközi tapasztalatok szerint kevés az összefüggés. Észtországban például az Internet-szolgáltatók alacsony számához kiugróan magas (közel 30\%-os) penetráció társul.

\section{2. ÁBRA}

Internet-szolgáltatók a megyei jogú városokban

(Internet service providers in mumicipalities)

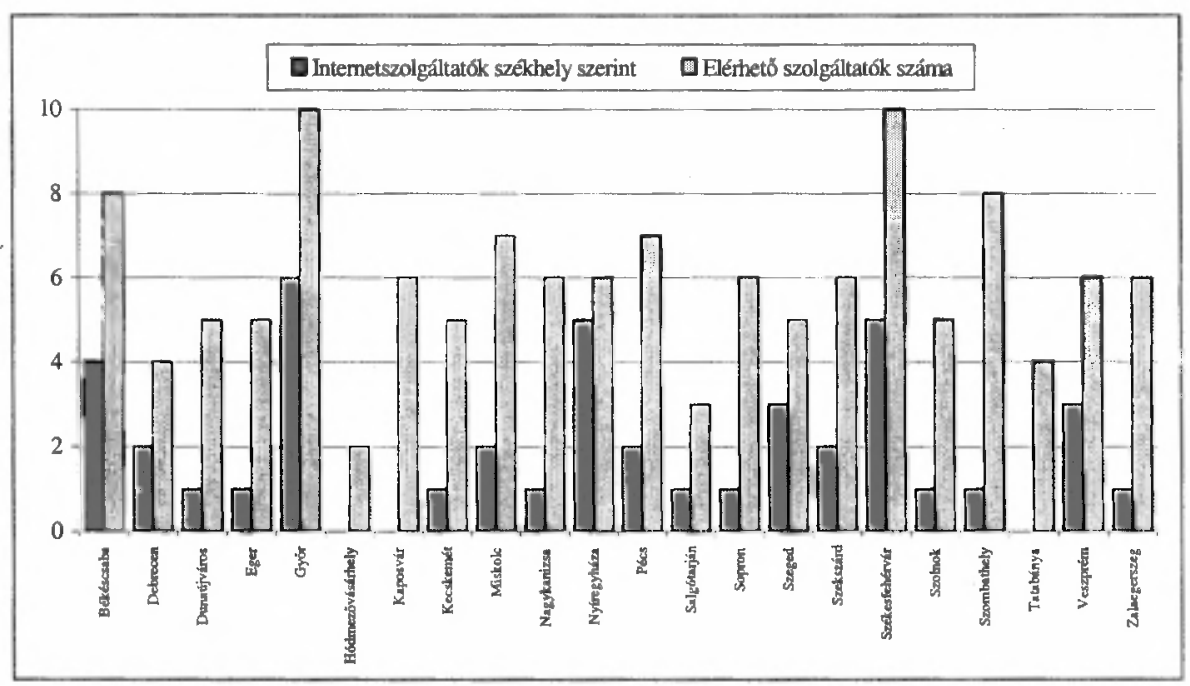

Forrás: www.isz.hu alapján saját szerkesztés.

\section{Az informatikusképzés}

Az információs társadalom alapját, fejlödésének kulcsát az infrastruktúra mellett az informatikával foglalkozó szakemberek jelentik. Az informatika képzés két klasszikus bölcsőjét a tudományegyetemek természettudományi karai (computer science kurzusok) és a müszaki egyetemek villamosmérnöki fakultásai (computer, software engineering) jelentik. Bár a világban a hatvanas, hetvenes évektől a mérnöki és hagyományos természettudományi bezártságból való kitörési kísérlet 
Barsi Boglárka - Csizmadia Zoltán: Egy nagyváros helyzete az információs társadalomban. Tér és Társadalom, 15. 2001. 2. 147-172. p.

TÉT XV. évf. 2001

jellemezte az informatikusképzést, önálló informatikai egyetemek vagy legalább karok jelennek meg, amelyeknek egyik föiránya a de-technicizálódás. Magyarországon mégis kevéssé ismert, hogy a hagyományos informatikusi tudás egyre kisebb szeletét jelenti az informatikának (ritka pozitív példa a megjelenó bankinformatika képzés a Budapesti Múszaki Egyetemen). Hasonlóképp a könyvtárosi szerep információ-szolgáltatói, Internet-könyvtárossá való átalakulása is gyerekcipóben jár (Nagy 1999).

Elemzésünkben a www.palya.hu oktatási portálra támaszkodtunk. A felsőoktatással foglalkozó oldalain lehetöség van az egyetemeket és főiskolákat az általuk kínált képzések alapján leválogatni. Az informatikusképzést nyújtó intézményeket aztán az egyes megyei jogú városokhoz rendeltük és összesítettük. Az intézmények darabszáma mellett hasonlóan összesítettük az oda első helyen jelentkezett hallgatók számát, az államilag finanszírozott és költségtérítéses helyek számát is.

Az informatikusképzés ${ }^{3}$ hazai jellemzőit áttekintve Budapest vezetō szerepe egyértelmüen szembetũnő. Budapesten található az informatikai képzést nyújtó intézmények egyharmada, 2001-ben az informatikát tanulni kívánók közel 60\%-a budapesti intézménybe adta be jelentkezési lapját. A fővároson kívül még 11 megyei jogú városban van informatikaképzés, köztük Győrben is. Győrbe kiemelkedően sokan jelentkeztek, különösen, ha a jelentkezettek számát lakosságarányosan számoljuk ki. A Nyugat-dunántúli régióban csak Győrben és Szombathelyen van informatikusképzés, gyaníthatóan Budapest vagy Veszprém szívja fel a hallgatókat. Azonban az itt végzett hallgatóknak valószínüleg csak kis hányada dolgozik majd a térségben.

Az informatikával és távközléssel foglalkozó cégek döntó többsége ugyanis Budapest székhellyel müködik. A jelentősebb hazai informatikai vállalkozásokat tömörítő Informatikai Vállalkozások Szövetségének tagjai közül csak kettő győri székhelyü, összesen 100 foglalkoztatottal. A többi megyei jogú város közül kiemelkedik Debrecen, Miskolc, Székesfehérvár, Szeged és Pécs, de még ezek a városok is csak 4-5 informatikai vállalkozásnak adnak otthont. $\mathrm{Az}$ informatikai vállalkozások egyértelmủen Budapestre koncentrálódnak (218). Ha ezeket az összes társas vállalkozás számához viszonyitjuk Budapest kiugró helyzete mérsékeltebben bár, de - akkor is megmarad, hiszen a vállalkozások 0,15\%-a foglalkozik informatikával. Győrben ez az arány csak 0,03\%. A megyei jogú városok közül a legjobb pozícióban Székesfehérvár van, ahol a vállalkozások 0,098\%-a múködik e szektorban. Székesfehérvár előnyös helyzete korábbi hagyományaival, valamint a Videoton romjain építkező új cégek és az Albacomp Rt. jelenlétével - amely az egyik legnagyobb számítástechnikai vállalkozás Magyarországon - magyarázható.

A számítástechnika, telekommunikáció a jövỏ iparágai, ezért fontosságuk piaci részesedésüket is jelentősen meghaladja, ugyanakkor gazdasági jelentőségük is növekvő tendenciát mutat. Éppen ezért tủnik meglepőnek, hogy a Győr-MosonSopron Megyei Munkaügyi Központ kutatásunk idején nem ajánlott informatikusnak állást, de a hazai nagyobb internetes álláskeresó oldalakat 
Barsi Boglárka - Csizmadia Zoltán: Egy nagyváros helyzete az információs társadalomban.

Tér és Társadalom, 15. 2001. 2. 147-172. p.

154 Barsi Boglárka-Csizmadia Zoltán

TÉT XV. évf. 2001

végignézve, sem találtunk egyetlen Györbe informatikust kereső hirdetést sem; két ajánlatot találtunk Északnyugat-Magyarország területére. Eközben a 231 fellelt hirdetés közel 60\%-a Budapestre keresett szakembert, további 23\%-a pedig kưllföldre. ( $\mathrm{Az}$ álláskeresés során a következó szolgáltatókat látogattuk meg: www.job4smarts.com, www.cvonline.hu, www.jobpilot.hu, www.allascentrum.hu, www.multijob.hu, www.jobline.hu, www.allasok.hu.)

\section{Internet-hozzáférés a közoktatásban}

A magyarországi „Középiskolai Internet Program” (Sulinet) 1996 szeptemberében indult a Múvelödési és Közoktatási Minisztérium támogatásával. A fizikai hálózat kiépitése azonban csak 1997-ben kezdődött el több koncessziós telefontársaság bevonásával. 1998. végétöl Sulinet/Irisz néven müködött tovább, ahol az Irisz név a megnövekedett jelentőségủ tartalomszolgáltatásra utalt.

A kialakított hálózat két szintre tagozódik. Az első szint, a gerinchálózat biztosítja a regionális csomóponti és külföldi csatlakozást, a második szint, a felhordóhálózat az iskolák és a gerinchálózat között teremt kapcsolatot. A nagyobb (500 fö feletti) iskolák általában $64 \mathrm{Kbit} / \mathrm{s}$ sebességü ISDN, míg az ennél kisebb intézmények ugyanilyen sebességü, modemes kapcsolatot alakíthatnak ki.

Elemzésünk során a Központi Fizikai Kutatóintézet honlapján (http://www.kfki.hu/education/iskola_koz.html) talallható, az Internet-kapcsolattal rendelkezö magyar középiskolákat és általános iskolăkat tartalmazó listát használtuk fel. A listán szerepló iskolák közuil a 22 megyei jogú városban és Budapesten található intézményeket kiválogattuk és összesítettük. Ahhoz, hogy az abszolút számokon túlmutató információt is nyerjünk, az Oktatási Minisztérium által készített, az összes magyar közoktatási intézményt tartalmazó jegyzéket használtuk fel (www.om.hu). A jegyzék alapján összesítettük az egyes megyei jogú városokban és Budapesten található középiskolákat és általános iskolákat. Így a két adatsor segítségével azt is meg tudtuk vizsgálni, hogy az iskolák hány százaléka van „behálózva”, azaz rendelkezik Internet-hozzáféréssel.

A magyar középiskolák Internet hozzáférése még korántsem teljes körü (3. ábra). Az általunk vizsgált városok közül csak Salgótarján és Nagykanizsa középiskolái csatlakoztak teljes körüen a világhálóra. Győrben a középiskolák $56 \%$-a rendelkezik Internet-hozzáféréssel, így a város - e mutató alapján - csak a 18. helyet foglalja el a megyei jogú városok listáján. A jövö nemzedékének versenyképessége szempontjából pedig elengedhetetlen lenne az iskolai hozzáférések növelése, hiszen ma még a háztartások nagyon kis hányada rendelkezik otthoni Internet kapcsolattal. Bár azt is elmondhatjuk, hogy az Internethez való iskolai hozzáférések arånya és a városok gazdasági fejlettsége között nem mutatható ki kapcsolat, nyilvánvalóan mert nem üzleti, hanem állami akarat döntötte el az iskolák bekapcsolását. $A z$ általános iskolák bekapcsolása később kezdödött (hiszen a program elsődlegesen a középiskolák „behálózását” tủzte ki célul), és még meglehetösen korlátozott az Internet-hozzáférésük (4. ábra). A legjobb helyzetben Dunaújváros van, ahol az általános iskolák közel 54\%-a rendelkezik Internet-kapcsolattal. Györ 17. a listán, 
Barsi Boglárka - Csizmadia Zoltán: Egy nagyváros helyzete az információs társadalomban. Tér és Társadalom, 15. 2001. 2. 147-172. p.

tehát az általános iskolák tekintetében sem túl kedvezö a városi tanulók helyzete, ráadásul az országos átlagnak csak a felét éri el a bekapcsoltság mértéke.

\section{3. ÁBRA}

Internet-hozzáférés a magyar középiskolákban

(Internet access in Hungarian secondary schools)

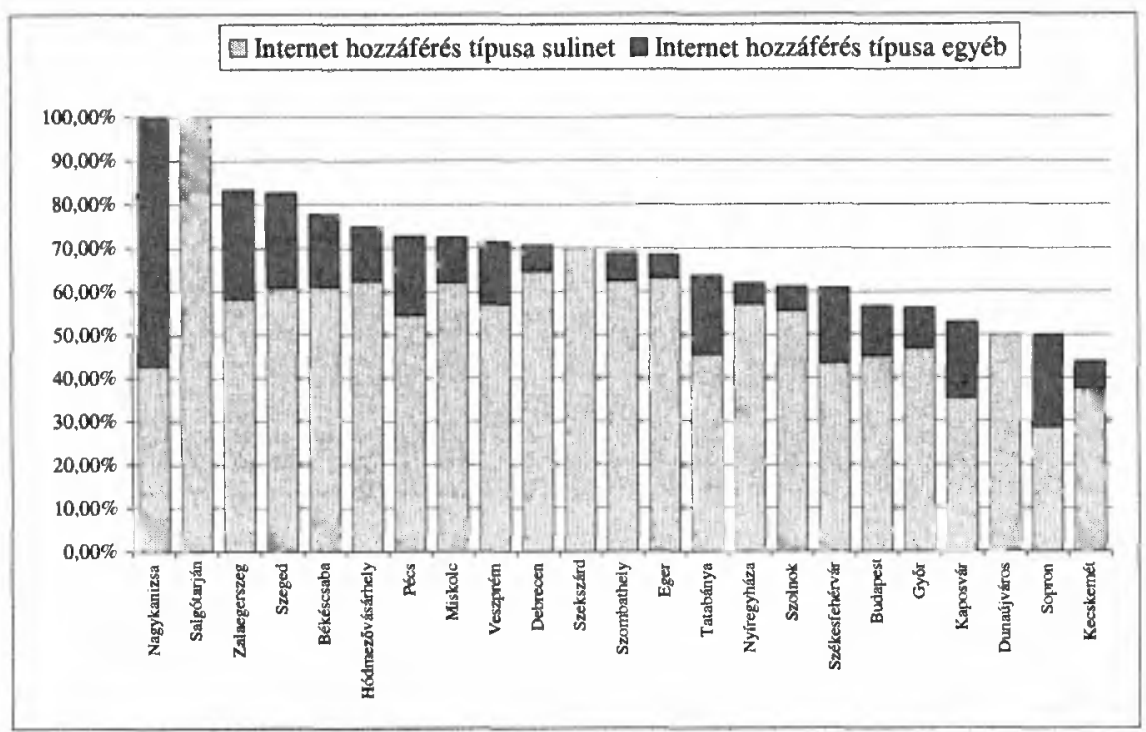

Forrás: http://www.kfki.hu/education/iskola_koz.html és www.om.hu alapján saját szerkesztés.

\section{4. ÁBRA}

Internet-hozzáférés a magyar általános iskolákban

(Internet access in Hungarian primary schools)

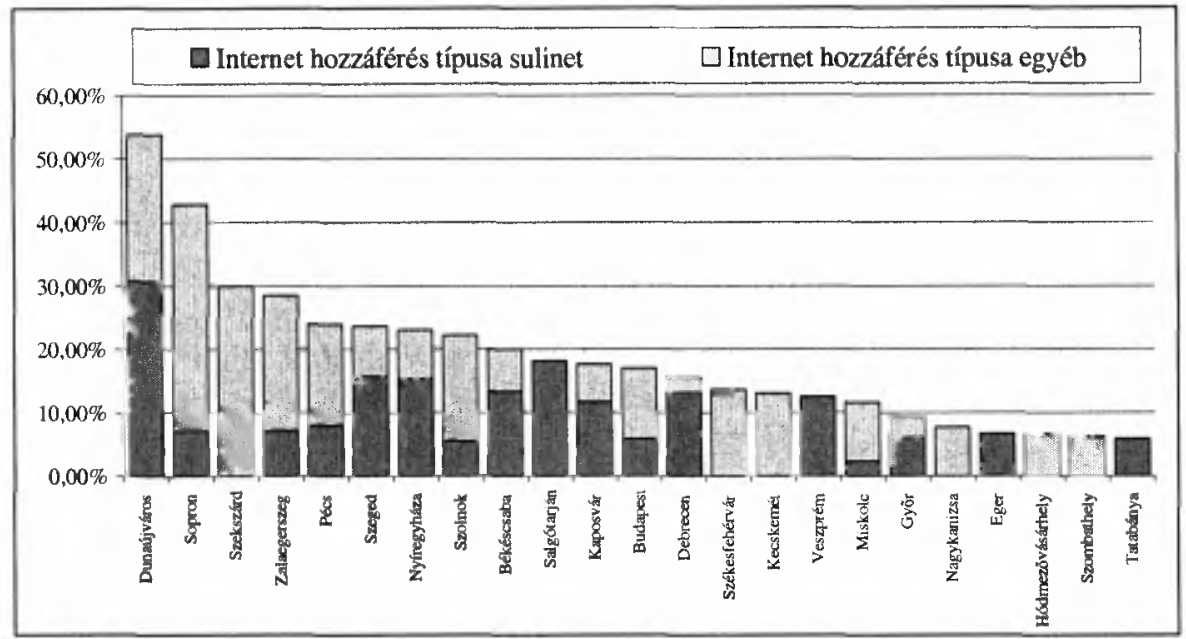

Forrás: http://www.kfki.hu/education/iskola_koz.html és www.om.hu alapján saját szerkesztés. 
Barsi Boglárka - Csizmadia Zoltán: Egy nagyváros helyzete az információs társadalomban.

Tér és Társadalom, 15. 2001. 2. 147-172. p.

156 Barsi Boglárka-Csizmadia Zoltán

TÉT XV. évf. 2001

Az Országos Közoktatási Intézet (OKI) és az Informatika-Számítástechnika Tanárok Egyesülete (ISZE) által 2000 nyarán elkészített középiskolai honlapelemzés során kialakított rangsor első 12 helyezettje között egy győri középiskola található, mégpedig a Jedlik Ányos Gépipari és Informatikai Középiskola a 11. helyen. Az első három helyet budapesti középiskolák foglalják el (Alternatív Közgazdasági Gimnázium, Puskás Tivadar Távközlési Technikum, Városmajori Gimnázium), az első vidéki iskola a negyedik a sorban (Teleki Blanka Gimnázium, Székesfehérvár). A fenti adatok figyelmeztetőek Györ szempontjából, hiszen a tanulás hatásfoka nem lesz kielégitő, ha a tanárok nem kapcsolják össze az iskolai tanulást az iskolán kivuuli tapasztalatszerzéssel, és ha nem használják ki az interaktív média által rendelkezésre álló széles körü lehetöségeket (Körösné Mikis 2001).

\section{Megyei jogú városok megjelenése az Interneten az egyes népszerübb WWW keresőrendszerek indexelése alapján}

Az alábbiakban bemutatott adatok az egyes keresőoldalak adatbázisainak 2001. június végi és augusztus végi állapotát tükrözik. Minden keresés az egyes városok nevére történt, tehát az eredményül kapott oldalszámok nem az adott városban létesített weboldalakat mutatják, hanem azoknak a lapoknak a számát, amelyekben az adott város neve megjelenik. Megítélésünk szerint a kapott számértékek arányukban jól felhasználhatók a városok internetes megjelenésének becslésére.

A lekérdezés a magyar keresőprogramok esetében a városok nevének nagy kezdőbetủ nélküli, de ékezetes, míg a külföldi keresőprogramok esetén a név ékezet nélküli alakjával történt.

Megállapíthatjuk, hogy Budapest az abszolút oldalszámok tekintetében messze listavezetö mind a hazai, mind a külföldi keresörendszerek gyüjtése alapján (ábránkba Budapest nem került be, hogy az kevésbé legyen torzított). Ez a túlsúly a lehetséges felhasználók számával elosztva már nem érvényesül, tehát elsősorban a văros méreteiböl és nem a megyei jogú városok általános fejlettségét meghaladó pozícióból ered. Így a nagyobb városok infokommunikációs fejlesztőinek reális esélyük van ennek a különbségnek a csökkentésére. Amellett, hogy ezeknek a fejlesztéseknek jelentős részét a helyi és regionális információs rendszerek kialakítása, megerősítése fogja adni, érdemes figyelembe venni, hogy a vidéki felhasználókat gyakran olyan földrajzi elhelyezkedéstöl független szolgáltatások csalogatják városuké helyett a budapesti oldalakra, amelyek kellö tỏke és vállalkozó szellem esetén bárhol megvalósíthatóak lennének az országban. Ha másra nem is, gondoljunk csak a Mailbox levelezörendszerre, melynek üzemeltetöje a Mail Hungary sátoraljaújhelyi székhelyü. Az ilyen típusú szolgáltatások magukban rejthetnék a lehetőségét fơvárosi felhasználók „kicsalogatásának”, és esetleg annak is, hogy a vidéki felhasználók más városok, régiók oldalaira is rendszeresen ellátogassanak. Mindezek mellett azonban a városok „,belső” életének minöségi megváltoztatása elsősorban a helyi szolgáltatások hálóra kerülésével, az ügyintézés és a helyi információszerzés gyorsitásával várható. Ezáltal nem csak az eddig a 
Barsi Boglárka - Csizmadia Zoltán: Egy nagyváros helyzete az információs társadalomban. Tér és Társadalom, 15. 2001. 2. 147-172. p.

TÉT XV. évf. 2001 - 2

Egy nagyváros helyzete ... 157

felcsatlakozás idejét követỏen a város környékét is elhagyó Internet-felhasználókat lehetne maradásra bírni, de megjelenhet egy új „WWW-olvasó” réteg is, amelyet bár nem vonzanak az Internet „korlátlan lehetőségei”, a mindennapjaiban számos problémát tud majd megoldani a helyi oldalak segítségével.

\section{5. ÁBRA}

A megyei jogú városok nevét tartalmazó indexelt oldalak egyes népszerübb magyar keresömotorokon (db oldaltalálat), 2001. augusztus

(Indexed pages containing the names of the municipalities in some popular Hungarian searching engines, August, 2001)

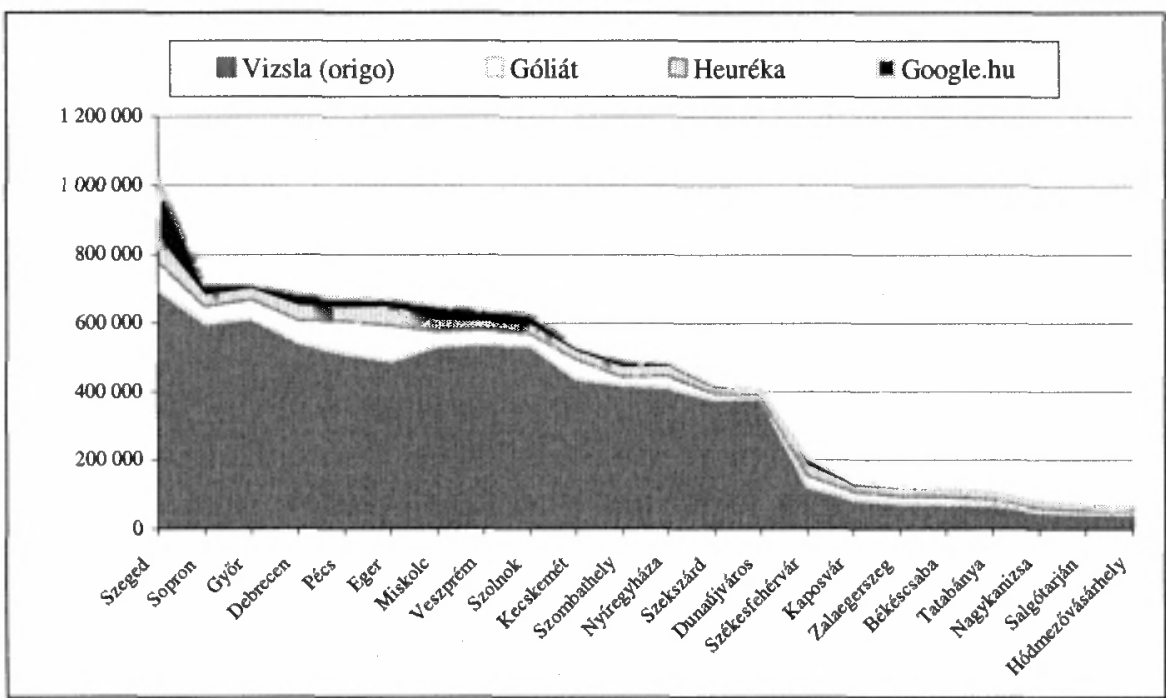

Forrás: Sajất adatgyüjtés.

A vizsgált városok rangsorában Székesfehérvártól jelentös szakadék húzódik (5. ábra). Noha ez a törés legélesebben a Vizsla keresőrendszer adataiban látható, a sorrend a többi keresőn történt lekérdezéseknél is hasonlóképp jelentkezik, és éppígy megfigyelhető a két hónappal korábbi (június végi) mintában. A rendszeresen a listák végére szoruló városokban feltétlenül el kellene gondolkodni valamely olyan hálózati „katalizátor” projekt életre hívásáról, amely segítené a felzárkózást. A kedvezőbb pozícióban lévő városok közé egyaránt bekerültek a nagyobb lakosságszámú, illetve több lehetséges felhasználót tömörítő települések és a kisebb városok is. Söt, úgy látszik, ez utóbbi csoport erösebb pozíciót harcolt ki magának. Mindez megerősíteni látszik a feltételezést, hogy - legalábbis bizonyos településméret felett - már ma sem elsösorban a lakosságszámtól függ a gazdag internetes megjelenés lehetösége.

Ahhoz, hogy meg tudjuk ítélni, milyen esélyekkel indul, illetve vesz részt egy-egy város ebben a versenyben, a következỏ dolgokat érdemes megfigyelni:

- Mekkora adattömeg található meg már most a várossal kapcsolatban a világhálón? 
Barsi Boglárka - Csizmadia Zoltán: Egy nagyváros helyzete az információs társadalomban.

Tér és Társadalom, 15. 2001. 2. 147-172. p.

158 Barsi Boglárka-Csizmadia Zoltán

TÉT XV. évf. 2001

- Milyen információs infrastruktúra áll rendelkezésre a városban akár a városvezetés, akár egyes szolgáltatók felügyelete alatt?

- Milyen esélyei vannak a helyi polgároknak a hálózati hozzáférésre, kik és milyen módon tudnák ezt kedvezó módon befolyásolni?

- Milyen lehetséges információ-szolgáltatók és -kezelök érhetơk el a városban, és milyen ezeknek a hozzáállása?

Mindezek a kérdések jól jelzik számunkra, hogy a városok egymás közötti versenyében (noha ez esetben a verseny kifejezés csak közvetve érvényes, hiszen a városok helyi információs rendszereik kialakitása során nem egymással versenyeznek, hanem egy optimális állapotot szeretnének mielőbb megközelíteni) mely város jutott önerőböl a legelöbbre, illetve melyeknek van behozni való lemaradásuk.

A nemzetközi keresőmotorok e pillanatban látszólag nem tesznek jelentős különbséget a magyar és idegen nyelvü oldalak között, számítani kell azonban arra, hogy hiába jut el egy hivatkozás alapján külföldi felhasználó ezekre az oldalakra, megfelelố fordítások nélkül tartalmuk kizárólag a hazai közönség számára lesz értékes.

A felhasználó szempontjából természetesen csak egy része az adott város sikeres hálózati magatartásának az, hogy kelló információ álljon rendelkezésre az egyes oldalakon. Ennek a tartalomnak egyszerre kell jól strukturáltnak és könnyen hozzáférhetőnek lennie. Míg egy városon belüli „oldalhálózat” kialakításakor az egyes lapok optimális esetben kellỏ számú hivatkozást tartalmaznak egymásra (és a megfeleló helyeken), vélhetöen sokan fogják a jövőben is az egyes keresőrendszerek útvesztóiben kezdeni az ismerkedést a városokkal.

Attỏl fúggỏen, hogy milyen eljárással indexelnek az egyes keresőprogramok, más-más megoldások születtek a látogatók eligazítására. Sajnálatos tény azonban, hogy igazán városi jelentöségünek mondható oldal csak csekély számban lelhetö fel a listákban. Fontos feladat volna, hogy az ilyen, kulcsszerepet betöltö - vagy ennek várományosaként született - oldalak üzemben tartói lehetőségeikhez mérten ápolják pozícióikat a keresőrendszerek listáin. (Több próbálkozás is ismert a bot-programok ítéletének kedvező befolyásolására, ezek - mértékkel és megfontolással - történő alkalmazása elősegíthetné a látogatószámok növekedését. Arról nem is beszélve, hogy az oldalak rendszeres frissítése, a megfelelỏen összeválogatott kulcsszavak, a kelló számú hivatkozás egy adott oldalra mutatóan stb. a napi használatban is minőségi javulást eredményezne.)

A Góliát keresőrendszer rögzíti azt is, hogy milyen hasonló szókapcsolatokat keresnek az internetezők a rendszeren. Győr esetében a következỏ gyakran keresett elemek jelennek meg: plaza, Györ térkép, Rádió Györ, Györ-Moson-Sopron megye települései, kereskedelmi kamara, munkaügyi központ, Györ város, Györ történelme, polgármesteri hivatal és végül Györ ingatlan. A város életének tehát szinte minden területére kíváncsiak lennének a polgárok. Érdekes megjegyeznünk, hogy a polgármesteri hivatalt beírva a keresőrendszerbe hét találatot kapunk, de a városi önkormányzat honlapja nincs ezek között. Ugyanígy nem jutunk el a 
Barsi Boglárka - Csizmadia Zoltán: Egy nagyváros helyzete az információs társadalomban. Tér és Társadalom, 15. 2001. 2. 147-172. p.

TÉT XV. évf. 2001 @ 2

Egy nagyváros helyzete ...

www.gyor-ph.hu oldalig akkor sem, ha a "Györ városi önkormányzat" szókapesolattal próbálkozunk. Márpedig így az érdeklődó internetező nem jut el a város egyik hivatalos oldalára, ezért nem is várható el töle, hogy az abban rejlö lehetőségeket ismerje vagy használja.

\section{Egy nagyváros helyzete az információs korban}

\section{A lakossági felmérés módszertana}

Kérdớves módszerrel próbáltuk meg feltárni az információs és kommunikációs technológiák elterjedtségét, az Internet-használattal kapcsolatos jellemzőket, az információs társadalommal szembeni lakossági várakozásokat Gyơrben. A kutatás elsődlegesen tényfeltáró, leíró jellegü, mivel ilyen részletességgel korábban nem álltak rendelkezésre megfelelỏ adatok a vizsgált településen élök informatikai jellemzőirỏl, az információs szolgáltatások igénybevételéről és a megkérdezettek szubjektív elvárásairól, céljairól. A helyzetelemző leíráson túl lehetőséget biztosít a felmérés arra is, hogy ok-okozati összefuggéseket, magyarázatokat keressünk a kapott eredményekre, kulönösen akkor, ha a meglévő hiányosságok tekintetében szeretnénk érdemleges válaszokat találni.

Maga a felmérés két nagyobb vizsgálati területre bontható. Az elsö rész Györ város informatikai helyzetét vizsgálja, a második a városi információs szolgáltatásokkal, lehetőségekkel, és nem utolsó sorban a lakosok információs igényeivel, „információ-fogyasztási szokásaival” foglalkozik. Mindkét területen kiemelt célként fogalmazódott meg, hogy az elemzésből kirajzolódjon a györi polgárok személyes véleménye a jelenlegi hiányosságok okairól és a preferált fejlesztési irányokról.

A helyzetelemzés alapját egy 500 före kiterjedó elemzési minta alkotja, amelybe véletlenszerüen kerülhertek be a 21 győri önkormányzati képviselöi választókerület lakosai, bizonyos reprezentativitási kritériumoknak megfelelöen. A 21 önkormányzati választókerület összlakossága 103514 fỏ (a teljes városi populáció nagyobb létszámú, de a mintavételi kritériumok miatt csak a 18-59 éves lakosságot tekintjük a teljes sokaságnak). Közülük választottunk ki 500 olyan személyt, akiket a lekérdezést végzỏ Marketing Centrum - Országos Piackutató Kft. munkatársai kérdớvünkkel megkerestek.

A megkérdezett 500 személy nem a teljes sokaságot reprezentálja, hanem csak a 18-59 éves kor közötti györieket. Ez azt jelenti, hogy az általunk bemutatott jellemzók és az adatokból levonható következtetések csak abban az értelemben hitelesek, ha nem vesszük figyelembe a vizsgált településen élő 18 év alatti fiatalkorúakat és az 59 évesnél idősebb, föként nyugdíjas korosztályt. Azért döntöttünk a redukció mellett, mivel a nyugdíjas korcsoport nagysága még jobban lecsökkentette volna a felmérés megbizhatóságát az informatikai rész kapcsán. A helyzetelemzés alapját képezó empirikus felmérés adatai reprezentatívak a nem, az életkor és a városon belüli területi elhelyezkedés tekintetében, tehát pontosan leképezik a 18-59 év közötti györi lakosságot. 
Barsi Boglárka - Csizmadia Zoltán: Egy nagyváros helyzete az információs társadalomban.

Tér és Társadalom, 15. 2001. 2. 147-172. p.

Az általunk összeállított kérdöív három tartalmi blokkra bontható. Az első részben szerepelnek az informatikai jellemzők feltérképezéséhez fontosnak tartott kérdések, amelyek a következö témák köré csoportosulnak:

- Kik férnek hozzá és milyen keretek között a különbözö számítástechnikai eszközökhöz, lehetöségekhez?

- Milyen motiváló elemek állnak a számítástechnikában érintettek mögött, és milyen korlátokba, gátakba ütköznek azok, akik eddig kimaradtak az informatikai lehetöségek elönyeiből?

- Milyen célra és milyen gyakorisággal használják a megkérdezettek a számítástechnikai eszközöket, lehetőségeket?

- Honnan származnak a számítástechnikához kapcsolódó ismereteik, és milyen formában tudnák továbbfejleszteni azokat?

- Milyen területeken szorgalmaznák a lakosok a városi informatikai technológiák és szolgáltatások fejlesztését?

- Milyen a számítástechnikában érintett győri lakosok beruházási hajlandósága a számítástechnikai termékek, és az internetes szolgáltatások piacán?

A második, tartalmilag teljesen elkülönululó vizsgálati területet a városi információs szolgáltatások ismeretével és használatával kapcsolatos kérdések jelentik:

- Melyek a legismertebb városi információs fórumok a sajtótermékek, televíziós csatornák, rádióadók és az internetes honlapok közül?

- Milyen gyakorisággal veszik igénybe a györiek a különbözö fórumokat, információszerzési lehetöségeket?

- Mennyire érdeklik a györieket a városukban történó dolgok, a várossal kapcsolatos információk (az aktuális napi hírektól a bevásárlási lehetőségekig)?

- A különböző témájú információs szükségletek kielégítéséhez melyek a legfontosabbnak itélt nyilvánossági fórumok?

A harmadik rész, amely a kérdóív végén szerepelt, a megkérdezettek statisztikaidemográfiai jellemzöit tartalmazza. Feltételezésünk szerint a számítástechnikai jellemzők és a nyilvánossági fórumokon keresztül biztosított információk "lakossági fogyasztási mintáit" nagymértékben befolyásolják az öröklött humán jellegü és a megszerzett kulturális és gazdasági erőforrások. Az adatokban a legjelentősebb eltérésekre az iskolai végzettség, a munkaerö-piaci helyzet, a foglalkozás típusa és a gazdasági erőforrásokkal való ellátottság (egy före eső havi családi nettó jövedelem, a tartós fogyasztási cikkek száma a háztartásokban) mentén bukkanhatunk.

\section{Az általános statisztikai-demográfiai mutatók}

Célszerü bemutatni a vizsgált minta általános jellemzőit a legfontosabb demográfiai és társadalmi mutatók alapján, hogy átlátható képet kapjunk arról, milyen társadalmi csoportokból áll össze az elemzés alapját képező adatbázis (1. táblázat). Az általános demográfiai mutatók vizsgálatunkban a következök: a 
Barsi Boglárka - Csizmadia Zoltán: Egy nagyváros helyzete az információs társadalomban.

Tér és Társadalom, 15. 2001. 2. 147-172. p.

TÉT XV. évf. 2001 — 2

Egy nagyváros helyzete ...

161

megkérdezett személyek neme, életkora, családi állapota, a közös háztartásban élök száma, a közös háztartásban élő aktív keresỏ személyek száma, a háztartásban éló kiskorúak száma. ${ }^{4}$

1. TÁBLÁZAT

A különbözö társadalmi jellemzök megoszlási alapadatai a teljes minta és a számitástechnikai érintettség alapjän kialakitott hozzáférési csoportokban

(Distribution of Social Characteristics in the Whole Sample and the two PC-access Groups)

\begin{tabular}{|c|c|c|c|c|c|c|}
\hline \multirow[t]{3}{*}{ Változók } & \multicolumn{2}{|c|}{$\begin{array}{c}\text { A teljes minta alapvetó } \\
\text { demográfiai és társadalmi } \\
\text { jellemzöi }\end{array}$} & \multicolumn{4}{|c|}{$\begin{array}{c}\text { Számítástechnikai érintettség } \\
\text { (hozzáfér személyi számítógéphez?) }\end{array}$} \\
\hline & \multirow{2}{*}{$\begin{array}{l}\text { Gyakoriság } \\
(\mathrm{N})\end{array}$} & \multirow{2}{*}{$\begin{array}{c}\text { Megoszlás } \\
\%\end{array}$} & \multicolumn{2}{|c|}{ Igen } & \multicolumn{2}{|c|}{ Nem } \\
\hline & & & (N) & $\%$ & $(\mathrm{~N})$ & $\%$ \\
\hline \multicolumn{7}{|l|}{$\mathrm{Nem}$} \\
\hline Férfi & 244 & 48,8 & 120 & 48,4 & 124 & 49,2 \\
\hline Nö & 256 & 51,2 & 128 & 51,6 & 128 & 50,8 \\
\hline Összes & 500 & 100 & 248 & 49,6 & 252 & 50,4 \\
\hline \multicolumn{7}{|l|}{ Korcsoportok } \\
\hline $18-24$ & 73 & 14,6 & 46 & 18,5 & 27 & 10,7 \\
\hline $25-29$ & 85 & 17,0 & 43 & 17,3 & 42 & 16,7 \\
\hline $30-39$ & 118 & 23,6 & 56 & 22,6 & 62 & 24,6 \\
\hline $40-49$ & 112 & 22,2 & 68 & 27,4 & 43 & 17,1 \\
\hline $50-59$ & 113 & 22,6 & 35 & 14,1 & 78 & 31,0 \\
\hline \multicolumn{7}{|l|}{ Családi állapot } \\
\hline Házas & 290 & 58,0 & 151 & 60,9 & 139 & 55,2 \\
\hline Nötlen, hajadon & 123 & 24,6 & 67 & 27,0 & 56 & 22,2 \\
\hline Elvált & 44 & 8,8 & 17 & 6,9 & 27 & 10,7 \\
\hline Özvegy & 13 & 2,6 & 2 & 0,8 & 11 & 4,4 \\
\hline Élettárssal él & 30 & 6,0 & 11 & 4,4 & 19 & 7,5 \\
\hline \multicolumn{7}{|l|}{ Legmagasabb iskolai végzettség } \\
\hline 8 általános vagy kevesebb & 56 & 11,2 & 10 & 4,0 & 46 & 18,3 \\
\hline Szakmunkásképzö & 133 & 26,7 & 29 & 11,7 & 104 & 41,3 \\
\hline Szakközépiskola & 126 & 25,3 & 71 & 28,7 & 55 & 21,8 \\
\hline Gimnázium & 70 & 14,0 & 47 & 19,0 & 23 & 9,1 \\
\hline Föiskola & 68 & 13,6 & 52 & 21,1 & 16 & 6,3 \\
\hline Egyetem & 46 & 9,2 & 38 & 15,4 & 8 & 3,2 \\
\hline \multicolumn{7}{|l|}{ Munkaviszony } \\
\hline Dolgozik & 353 & 70,6 & 181 & 73,0 & 172 & 68,3 \\
\hline Tanuló & 45 & 9,0 & 38 & 15,3 & 7 & 2,8 \\
\hline Nyugdíjas & 43 & 8,6 & 5 & 2,0 & 38 & 15,1 \\
\hline \multicolumn{7}{|l|}{ Foglalkozás típusa } \\
\hline Szakmunkás & 90 & 24,9 & 18 & 9,7 & 72 & 40,9 \\
\hline Segéd- és betanított munkás & 40 & 11,0 & 2 & 1,1 & 38 & 21,6 \\
\hline Văllalkozó & 46 & 12,7 & 27 & 14,5 & 19 & 10,8 \\
\hline Úgyviteli & 29 & 8,0 & 18 & 9,7 & 11 & 6,3 \\
\hline $\begin{array}{l}\text { Szakalkalmazott } \\
\text { (felsö és középfokú) }\end{array}$ & 118 & 32,6 & 92 & 49,5 & 26 & 14,8 \\
\hline Vezető (alsó, közép, felsõ) & 34 & 9,4 & 27 & 14,5 & 7 & 4,0 \\
\hline \multicolumn{7}{|l|}{$\begin{array}{l}\text { Egy fóre jutó havi családi nettó } \\
\text { jövedelem }\end{array}$} \\
\hline Kevesebb, mint $20000 \mathrm{Ft}$ & 42 & 10,6 & 15 & 8,3 & 27 & 12,5 \\
\hline $20001-40000 \mathrm{Ft}$ & 171 & 43,2 & 59 & 32,6 & 112 & 52,1 \\
\hline $40001-60000 \mathrm{Ft}$ & 114 & 28,8 & 56 & 30,9 & 58 & 27,0 \\
\hline Tơbb mint $60000 \mathrm{Ft}$ & 61 & 13,4 & 45 & 24,9 & 16 & 7,5 \\
\hline $\begin{array}{l}\text { Tartós fogyasztási cikkek száma } \\
\text { Kơzépértékek (maximális } \mathrm{db}=16 \text { ) }\end{array}$ & 9 & & 10 & & 7 & \\
\hline
\end{tabular}

Forrás: Kérdóf́vek 2001. 
Az eltérö strukturális pozíciókra és egyenlötlenségekre a kulturális erőforrásokat reprezentáló legmagasabb iskolai végzettség változója utal; a társadalmi munkamegosztásban elfoglalt munkaerő-piaci helyzetre a munkaviszony jellege és a jelenlegi foglalkozási típus változói alapján következtethetünk. A gazdasági erőforrásokkal való ellátottság mértékét pedig három változó összevont elemzése alapján lehet pontosabban és megbízhatóbban meghatározni. A megkérdezett személyek anyagi helyzetére utal az, hogy (1) mekkora az átlagos egy före jutó havi nettó jövedelem a válaszadók háztartásában, (2) hogy hol helyeznék el magukat egy olyan 10 fokozatú skálán, ahol az egyes jelenti a legszegényebb embereket, az ötös az átlagos jövedelmủeket, a tízes pedig a leggazdagabbakat mutatja, (3) illetve milyen tartós fogyasztási cikkekkel rendelkeznek.

$\mathrm{Az}$ elemzési mintába került személyek legfontosabb társadalmi jellemzöi a következők: (1) 18-59 év közöttiek, (2) a megkérdezettek átlag életkora 38 év, (3) az átlagos háztartás 3 fóbőll áll, (4) az összes háztartás 60\%-ában nem él 18 év alatti eltartott személy, (5) majdnem $60 \%$ házas, (6) több mint $20 \%$ diplomás, bár túlnyomóan fỏiskolai végzettségüek, (7) 70\%-uk jelenleg munkaviszonyban áll, (8) a két legnagyobb foglalkozási csoport a kék-galléros fizikai (35,9\%), és a fehérgalléros túlnyomóan hivatali, szakalkalmazotti $(40,6 \%)$ munkakörben dolgozókból áll, (9) az átlagos egy före jutó havi jövedelem 30-40 000 Ft kőzőtt mozog.

\section{Számitástechnikai jellemzók}

Ahogy említettük, a lekérdezés elött nem ismertuk pontosan azokat a személyeket, akik használnak számítástechnikai eszközöket, és igénybe veszik az ilyen tárgyú szolgáltatási lehetőségeket.

Először ismertetjük a személyi számítógéphez és az Internethez való hozzáférés adatait a vizsgált minta esetén, majd bemutatjuk, hogy kik azok a személyek, társadalmi csoportok, akik hozzáférnek a számítástechnikai eszközökhöz és szolgáltatásokhoz, végül megvizsgáljuk a két elkülönülö csoport (a számítástechnikában érintett lakosok - az eddig kimaradt, nem felhasználói jellegủ csoportok) társadalmi jellemzöit, külőnös tekintettel a kulturális és gazdasági eröforrásokra.

\section{Hozzáférés a számitástechnikai eszközökhöz, szolgáltatásokhoz}

Ahhoz, hogy pontosan lokalizálni tudjuk azt a felhasználói csoportot a györi mintánkban, amelynek a tagjai hozzáférnek számítástechnikai eszközökhöz és az internetes szolgáltatásokhoz, megkérdeztük a lakosokat arról, hogy a saját háztartásukban, a munkahelyükön vagy más helyen használnak-e számítógépet és Internetet. Így nemcsak arra nyílt lehetőségünk, hogy feltérképezzük a felhasználási lehetőségek belső szerkezetét, hanem a válaszok összevonásával ki tudtuk alakítani az informatikában felhasználói szinten érintett győri személyek csoportját. 
Barsi Boglárka - Csizmadia Zoltán: Egy nagyváros helyzete az információs társadalomban. Tér és Társadalom, 15. 2001. 2. 147-172. p.

TÉT XV. évf. 2001 匹 2

Egy nagyváros helyzete...

163

A megkérdezett személyek fele (otthon, munkahelyen, iskolában, barátnál vagy ismerősnél) hozzáfér személyi számítógéphez (6. ábra). Az internetes lehetöségekhez pedig majdnem minden harmadik gyốri személy hozzáfér. $\mathrm{Ha}$ a felhasználói csoportra vetítve vizsgáljuk az arányokat, akkor azt mondhatjuk, hogy a számítógép-használók 60\%-a az Internethez is hozzáfér.

\section{6. ÁBRA}

Számitógép-és Internet-hozzáférési adatok a vizsgált településen

(PC and Internet access in the City)

Az igen válaszok aránya a teljes minta esetén $(N=500)$

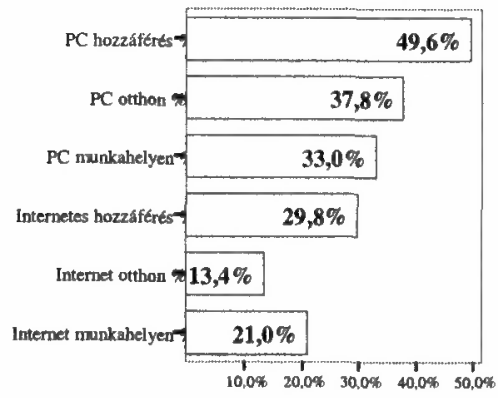

Az igen válaszok aránya o pc-használok kỏrében $(N=248)$

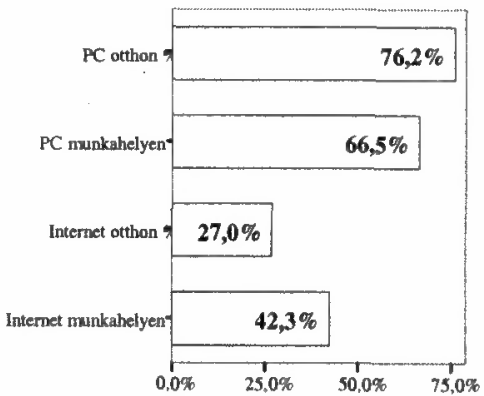

Forrás: Kérdöívek 2001.

Saját háztartásukban a megkérdezettek 38\%-ának van számítógépe. ${ }^{5}$ Valamivel kisebb létszámú azoknak a csoportja, akik a munkahelyükön vagy valamilyen oktatási intézményben férnek hozzá számítógéphez (33\%). Azok a személyek pedig, akik más alternatív megoldást választanak a PC-használat során, legnagyobb valószínüséggel (62\%-uk) valamelyik barátjuknál, a szomszédban vagy ismerősnél férnek hozzá a számítógéphez. Feltételezésünk szerint az otthoni és a munkahelyi felhasználók jelentỏs része ugyanaz a személy. A két változó korrelációja 0,4 , ami nem olyan erös, de mindenképpen jelzi a pozitív összefüggést. A teljes minta $21 \%$-a a saját otthonában és a munkahelyén vagy az iskolájában is használ személyi számítógépet. Ök alkotják azt a felhasználói keménymagot, akik a legintenzívebben élnek a számítástechnikai szolgáltatások és technológiák lehetöségeivel. Azon személyek $65 \%$-a, akik hozzáférnek személyi számítógéphez a munkahelyen vagy iskolában, saját otthonukban is rendelkeznek PC-vel. Vagy egy másik megközelítésben azt mondhatjuk, hogy akiknek otthon nincsen gépük, azok $81 \%$-a a munkahelyén sem használ számítástechnikai eszközöket.

Felhasználói aspektusuk alapján a megkérdezetteket négy alcsoportra lehet bontani. 256 olyan személy került a megkérdezettek közé $(51,2 \%)$, akik nem férnek hozzá személyi számítógéphez sem otthon, sem a munkahelyen vagy valamilyen oktatási intézményben. 57 fő $(11,4 \%)$ csak a munkahelyén, 82 fö $(16,4 \%)$ csak a 
Barsi Boglárka - Csizmadia Zoltán: Egy nagyváros helyzete az információs társadalomban.

Tér és Társadalom, 15. 2001. 2. 147-172. p.

164 Barsi Boglárka-Csizmadia Zoltán

TÉT XV. évf. 2001 a 2

saját háztartásában és 105 fơ $(21,0 \%)$ mindkét területen használ személyi számítógépet ${ }^{6}$.

Az Internet-használók köre értelemszerủen szúkebb, bár így is a teljes minta 30\%-a, tehát 149 fỏ valamilyen formában hozzáfér az internetes lehetőségekhez. A megkérdezettek egyötöde a munkahelyén tud internetezni, 13\%-uk pedig otthonról is eléri a világhálót. Ebben az esetben is a barátok, az ismerösök és a szomszédok a leggyakoribb internetezésre lehetőséget biztosító személyek abban az esetben, ha valaki nem fér hozzá a hálózathoz sem a saját háztartásában, sem a munkahelyén, sem az iskolában (minden második személy közülük ezt a megoldást választja). Azok a személyek, akik a munkahelyükön rendelkeznek Internetettel (105 fö) nagy valószínűséggel nem fogják bevezettetni saját háztartásukba (72\%-uk csak a munkahelyén fér hozzá), céljaiknak megfelel a munkahelyi használat is. Értelemszerủen magasabbak az arányok akkor, ha nem az összes megkérdezettre vetítve vizsgáljuk az adatokat, hanem csak a PC-hozzáféréssel rendelkezök körében. Közülük minden negyedik megkérdezettnek van otthon Internet csatlakozása, $42,3 \%$-uk pedig a munkahelyén is rá tud csatlakozni a világhálóra.

A 149 hozzáféréssel rendelkező személy 22,8\%-a egyetlen területen sem használja az Internetet, így a tényleges felhasználók csoportja lecsökken 115 före, ami a teljes minta esetén $23 \%$-os arányt jelent. Mindez tehát azt jelenti, hogy a megkérdezettek 6,8\%-a hozzáfér az Internethez, de nem használja azt. A számitástechnikában érintett személyek csoportjára (248 fö) vetítve úgy módosulnak az adatok, hogy a PC-használók 46,4\%-a ténylegesen internetezik, míg 13,7\%-uk csak hozzáfér az internetes lehetőségekhez és szolgáltatásokhoz, de valójában nem használja azokat.

A saját háztartásban Internet-összeköttetéssel rendelkezők 52,3\%-a faxmodemen keresztül éri el a világhálót, 30,8\%-uk pedig ISDN vonalon. A munkahelyi Internethozzáférés adataiban a megkérdezettek egynegyede nem tudott nyilatkozni. Ők nem ismerik pontosan, hogy a munkahelyükön milyen formában érik el a hálót. A faxmodemek nem olyan elterjedtek, mint a háztartási felhasználás esetén (13,3\%), inkább az ISDN $(36,2 \%)$ és a bérelt vonal $(18,1 \%)$ a gyakori. Bár a válaszok hiánya csökkenti az adatok megbízhatóságát, ennek ellenére az eltérések így is érzékeltethetőek, melyben feltehetöen a legfontosabb differenciáló elem a csatlakozási lehetőségek eltérö árszinvonala. A domináns, mondhatni monopolhelyzetben lévő Internet-szolgáltató a Matáv-Axelero: az otthoni Internetelöfizetők $61 \%$-a nála rendelte meg a szolgáltatást (az eredmény csak orientáló jellegủ az alacsony elemszám miatt).

\section{Hozzáférési/felhasználási csoportspecifikumok}

A vizsgálatba bevont 500 győri lakost két csoportra lehet bontani. A ,jelenleg már hozzáférōk" csoportjăhoz tartoznak azok a megkérdezettek, akik vagy a saját otthonukban, a munkahelyükőn, iskolájukban, vagy más intézményesített formában hozzáférnek személyi számítógéphez, illetve rokoni, baráti, szomszédi vagy 
Barsi Boglárka - Csizmadia Zoltán: Egy nagyváros helyzete az információs társadalomban. Tér és Társadalom, 15. 2001. 2. 147-172. p.

TÉT XV. évf. 2001 - 2

Egy nagyváros helyzete...

165

ismerősi kapcsolataikon keresztuil érhetik el a személyi számítógépet, ha használni szeretnék. A „jelenleg még nem hozzáférók" csoportjába azok a válaszadók kerültek, akik semmilyen formában sem férnek hozzá személyi számítógéphez, és ebböl következően a számítástechnikai blokkra vonatkozó kérdésekre nem tudtak érdemi választ adni. Felmerül a kérdés: milyen csoport-specifikus jegyekkel rendelkezik a két elkülönüló csoporthoz tartozó lakosság az általános demográfiai és társadalmi mutatók tükrében?

A két csoport társadalmi jellemzőinek különbségeit az 1. táblázat tartalmazza a nem, az életkor, a családi állapot, az iskolázottság, a munkaviszony és a jelenlegi foglalkozás, illetve az anyagi helyzet tekintetében.

Önmagában a megkérdezettek neme nem minösült differenciáló elemnek. A férfiak és a nök aránya egyenletes eloszlást mutat, és mindkét csoport esetén szinte megegyezik a teljes mintára vetített arányokkal. A családi állapot szerint a házasságban élök és a nötlenek, hajadonok felülreprezentáltak a hozzáférök csoportjában, bár ebben az esetben a háttérben a kor és más strukturális jellemzök állnak, nem pedig a háztartás családi formája. A demográfiai mutatók tekintetében tehát nem bukkanhatunk szignifikáns eltérésekre. Egyedüli kivétel a minta kor szerinti megoszlása lehet, hiszen a számítástechnikai eszközök és szolgáltatások igénybevétele összefüggésben áll - legalább is jelenleg - az emberek életkorával. A várakozásoknak megfelelöen nagyobb arányban szerepelnek a 18-29 éves korcsoport tagjai a hozzáférők között, és az 50-59-éves korosztály a nemhozzáférök közel egyharmadát jelenti, ami arra utal, hogy az idősebb korosztály körében jóval többen idegenkednek a számítástechnikától. A legmagasabb hozzáférési arány a 18-24 évesek körében figyelhető meg (63,0\%), illetve a $40-49$ évesek korcsoportjában ${ }^{7}(61,3 \%)$, ezzel szemben a legidösebb korosztály (50-59) közel kétharmada nem tudott válaszolni a számítástechnikai témában feltett kérdéseinkre.

Jelentős szerkezeti eltolódások figyelhetőek meg a két alcsoport összetételében a legmagasabb iskolai végzettség alapján (a teljes minta jellemzöihez viszonyítva), ami a kulturális erőforrások differenciáló erejére utal az informatikai technikák és szolgáltatások felhasználása/igénybevétele esetén. A hozzáférők csoportjában kevesebb mint 15\%-os azoknak az aránya, akik legfeljebb szakmunkás végzettséggel rendelkeznek (kevesebb mint 8 általános, 8 általános vagy szakmunkásképzö), ezzel szemben a nem hozzáférőket tömörítő csoport majdnem kétharmada nem rendelkezik még középfokú végzettséggel sem (a nem-hozzáférők több mint $40 \%$-a szakmunkás végzettséggel bír). Markánsan elkülönül a két csoport a végzettségi hierarchia felső szegletében is. A felsőfokú végzettséggel rendelkezők aránya nem éri el a 10\%-ot a nem-hozzáférők között, míg a számítástechnikai kérdésekre válaszolók $21,1 \%$-a föiskolai, $15,4 \%$-a pedig egyetemi diplomával rendelkezik. A végzettségi mutatók szerkezeti eltolódását összefoglaló jelleggel a 7. ábra mutatja be. 
Barsi Boglárka - Csizmadia Zoltán: Egy nagyváros helyzete az információs társadalomban.

Tér és Társadalom, 15. 2001. 2. 147-172. p.

\section{7. ÁBRA}

A két csoport iskolai végzettség szerinti összetétele

(The distribution of the highest year of school divided by PC access)

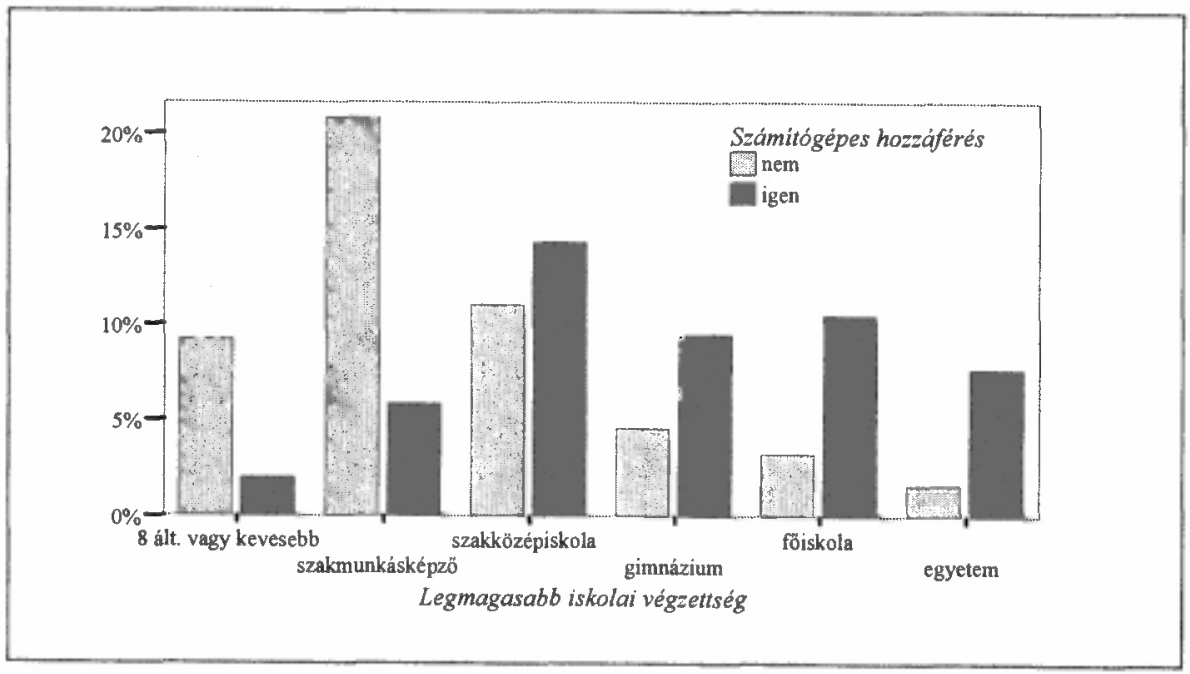

Forrás: Kérdöivek 2001.

Ha a különbözỏ végzettségi kategóriákon belül vizsgáljuk meg a hozzáférési arányokat, akkor még szembetünöbbek az eltérések. A vizsgált településen megkérdezett, legfeljebb általános iskolai végzettséggel rendelkező válaszadók $82 \%$-a nem tudott válaszolni a számítástechnikai kérdésekre, tehát nem tekinthetó PC-használónak, de még hozzáférỏnek sem. Az iskolai végzettség növekedésével, folyamatosan csökken a ,jelenleg még nem hozzáféró" személyek aránya ${ }^{8}$. Az egyetemi végzettséggel rendelkező személyek több mint 80\%-a hozzáfér valamilyen keretek között személyi számítógéphez. Jelenleg a számítástechnikai lehetöségekböl és szolgáltatásokból kimaradó györiek mindenképpen az alacsonyabb iskolai végzettségü lakópolgárok körében találhatók meg a legnagyobb arányban. Az adatok önmagukért beszélnek: a ,jelenleg még nem hozzáférök" között a válaszolóknak csupán 18,5\%-a rendelkezik legalább gimnáziumi (vagy föiskolai-egyetemi) végzettséggel egy olyan felmérésben, amely nem tartalmazza a nyugdíjas korosztályt, illetve a 18 év alatti lakosokat, és egy magyarországi léptékkel mérve - fejlödó nagyvárosi populációból történt a mintavétel.

$\mathrm{Az}$ iskolai végzettség alapján ismertetett eltérések szinte pontosan megismétlödnek, ha a foglakozási szerkezetre vonatkozóan vizsgáljuk a hozzáférési lehetőségeket. A nem-hozzáférői kör kétharmada szakmunkásként, illetve segéd vagy betanitott munkásként dolgozik (a szakmunkás foglalkozásúak aránya $41 \%$ ), tehát alapvetỏen olyan fizikai, kék-galléros munkakörben, ahol az esetek legnagyobb részében nem jelent munkaerö-piaci alapkövetelményt vagy elönyt a számitástechnikai ismeret. Ezzel szemben a hozzáféröi alcsoportban, a fizikai munkakörökben dolgozók aránya nem több 10\%-nál. Minden második személy 
Barsi Boglárka - Csizmadia Zoltán: Egy nagyváros helyzete az információs társadalomban. Tér és Társadalom, 15. 2001. 2. 147-172. p.

TÉT XV. évf. 2001 - 2

Egy nagyváros helyzete... 167

szakalkalmazottként dolgozik, és a vezető beosztásúak aránya is nagyon magas (15\%). A foglalkozási szerkezet eltolódásait a 8. ábra tartalmazza.

\section{8. ÁBRA}

A két csoport foglalkozási szerkezetének eltérései

(Differences in occupational structure in the two PC-access groups)

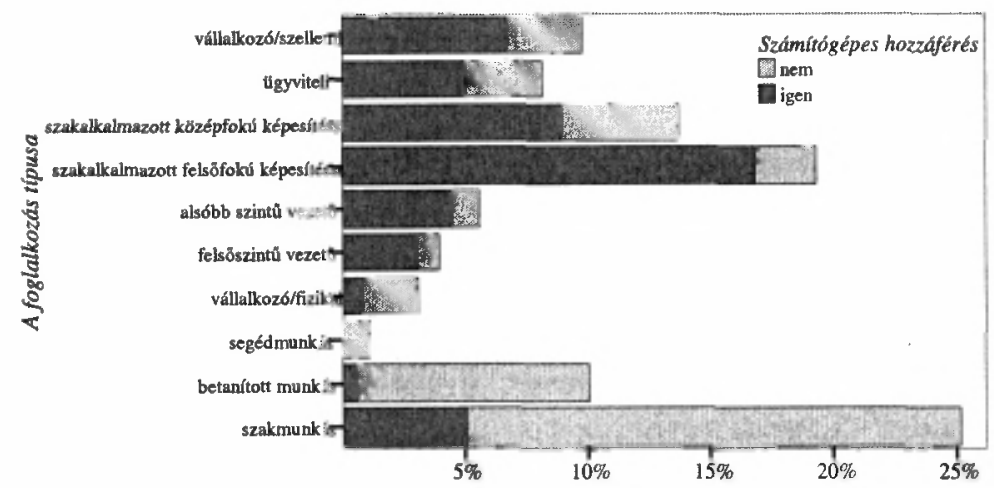

Forrás: Kérdōívek 2001.

$\mathrm{Az}$ adatok egyértelmủvé teszik, hogy a számítástechnikai érintettség kérdésében alapvető szerepe van a munkaviszonynak és a foglalkozási szerkezetben elfoglalt pozíciónak ${ }^{9}$. A 90 fös szakmunkáscsoport $80 \%$-a, a 40 fós segéd- és betanított munkás blokk 95\%-a nem tudott válaszolni a számítástechnikai témájú kérdésekre, ebböl következően nem használnak személyi számítógépet sem. Ezzel szemben a felső fokú képesítéssel rendelkező szakalkalmazott réteg majdnem kilenctizede, a középfokú képesítésủ szakalkalmazottak kétharmada, az ügyviteli munkakörben dolgozók $60 \%$-a hozzáfér személyi számítógéphez valamilyen formában (a munkahelyưkoön nagy valószínüséggel).

A legfontosabb eredménye a foglalkozási típusok szerinti vizsgálatnak az, hogy az olyan foglakozási területen dolgozó személyek, amelyek jelenleg még nem igénylik a számítástechnikai eszközök ismeretét és használatát, alapvetően idegenek a számítástechnika világában, nem használnak ilyen eszközöket a munkahelyen, a saját háztartásban, és még a barátoknál, rokonoknál, ismerösöknél, esetleg a szomszédoknál sem érik el a számítógép nyújtotta lehetöségeket. Az összes foglalkoztatott megkérdezett ( $\mathrm{N}=353$ ) közül 130 személy használ a munkájához személyi számítógépet $(36,8 \%)$. A munkahelyen biztosan használó személyek közül mindőssze heten sorolták magukat be a fizikai jellegü munkakörbe (mindannyian szakmunkások), ez azt jelenti, hogy a munkahelyi felhasználók 95\%-a vezetői, szakalkalmazotti, ügyviteli munkakörben dolgozik, vagy nem fizikai jellegú tevékenységet üző vállalkozó. Egyértelmü, hogy a foglalkozás típusa alapvetően 
Barsi Boglárka - Csizmadia Zoltán: Egy nagyváros helyzete az információs társadalomban.

Tér és Társadalom, 15. 2001. 2. 147-172. p.

behatárolja a PC-használat körét, és ebben az értelemben nem meglepőek az eredmények. A komoly problémát az jelenti, hogy az otthon biztosan hozzáférők körében ( $N=133$ a foglalkoztatottakra vetítve) is nagyon alacsony a fizikai munkakörben dolgozó személyek aránya. Az összes megkérdezett 26,6\%-a (133fö) olyan személy, aki a lekérdezés idöpontjában rendelkezett állással és a saját háztartásában hozzáfért személyi számítógéphez. Közülük csupán 23 személy dolgozik fizikai jellegủ munkakörben, ez a jelenleg dolgozó és otthon személyi számítógéphez hozzáférök csoportjának mindössze 17\%-a. A következtetésünk az, hogy a számítástechnikai eszközöktől mentes munkahelyi környezetben dolgozók jelentősen kisebb arányban jelennek meg a PC-használók között a munkahelyi használaton kívül is.

A kulturális erőforrások mentén megfigyelt társadalmi egyenlőtlenségek, és a foglakozási szerkezet struktúrája előre vetíti, hogy a rendelkezésre álló anyagi eröforrások mennyiségében és minőségében is komoly társadalmi különbségekre bukkanhatunk, ha a két csoport társadalmi háttérjellemzőinek anyagi oldalát vizsgáljuk meg. A PC-használók körében felülreprezentáltak a magas végzettségü és a kedvezőbb jövedelmi lehetöségeket nyújtó foglalkozások tagjai, ezért egyértelmü, hogy a jövedelmi skálán is komolyabb erőforrásokhoz férnek hozzá e csoport tagjai, ami az informatikai technológiák- és szolgáltatások használatakor jelentős, ha nem a legjelentösebb befolyásoló elem az egyének humán jellegü erőforrásain, személyes mentalitásán, attitüdjein túlmenően. A hozzáféréssel nem rendelkezök csoportjában a háztartások majdnem kétharmada nem tudott $40000 \mathrm{Ft}$ ot maghaladó egy fỏre jutó havi családi nettó jövedelemről beszámolni a felmérés időpontjában, bár az érintett háztartások négyötödében legalább a $20000 \mathrm{Ft}$-ot elérte a havi jövedelem egy före bontott összege. Ezzel szemben a hozzáférök csoportjában legalább minden második háztartás $40000 \mathrm{Ft}$ feletti jövedelemröl számolt be, és minden negyedik olyan személy, aki hozzáfér számítástechnikai eszközökhöz több mint $60000 \mathrm{Ft}-0$ s egy före esö havi nettó családi jövedelemmel rendelkezik ${ }^{10}$.

A gazdasági erőforrások kitüntetett szerepét a tartós fogyasztási cikkek mutatói is megerősítik, és a jövedelmi adatoknál megbizhatóbban képezik le a megkérdezett lakosság jelenlegi és múltbeli tulajdoni, vagyoni alapú erőforrásait ${ }^{11}$. Szigorúan mennyiségi értelemben, mindenképpen többtipusú tartós fogyasztási cikkel rendelkeznek azok a háztartások, ahol a megkérdezett személy érintett volt a számítástechnikai eszközök és szolgáltatások világában (átlagosan tíz eltérö tartós fogyasztási cikk van a birtokukban, szemben a kimaradók hetes átlagával).

A számítógép használat és a gazdasági erőforrások nagysága közti összefüggéseket (0,497-es korreláció 0,01-es szignifikancia szinten) a 9. ábra lépcsőzetes szerkezete jól érzékelteti. A tartós fogyasztási cikkek számának növekedésével egyre nagyobb arányban jelennek meg a hozzáférők, azaz minél kedvezöbb egy háztartás anyagi helyzete a tartós fogyasztási cikkek tekintetében, annál nagyobb valószínüséggel férnek hozzá számitástechnikai eszközökhöz és szolgáltatásokhoz a háztartás tagjai. 
Barsi Boglárka - Csizmadia Zoltán: Egy nagyváros helyzete az információs társadalomban. Tér és Társadalom, 15. 2001. 2. 147-172. p.

TÉT XV. évf. 2001 ш 2

Egy nagyváros helyzete ...

169

\section{9. ÁBRA}

A két csoport gazdasági erőforrásainak egyenlötlenségei

a tartós fogyasztási cikkek száma alapján

(Differences in consumer goods in the two PC-access groups)

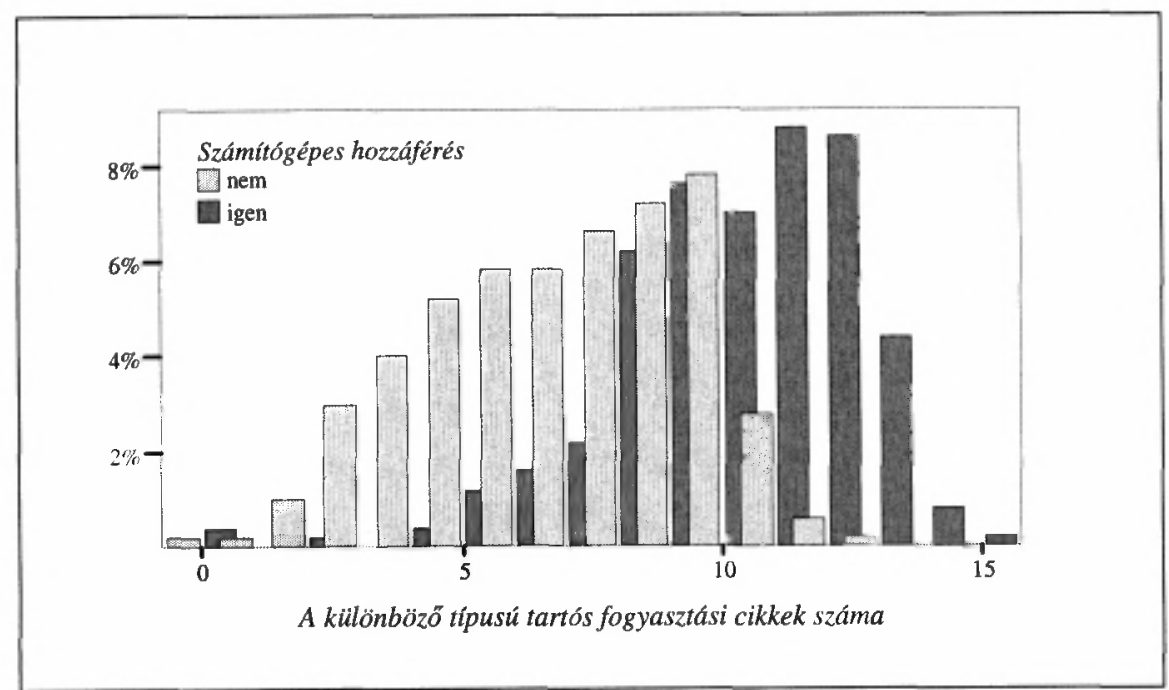

Forrás: Kérdōívek 2001.

A különböző jellegü tartós fogyasztási cikkek esetén megfigyelhetỏ tulajdonlási arányokból arra következtethetünk, hogy a hazai viszonyok között egy városi populációban alapvetônek minösülö eszközökben (televízió, mosógép, rádió, fényképezőgép, vezetékes telefon) nem figyelhetók meg szignifikáns különbségek a két csoport esetén. Az igazi választóvonalat azok a fogyasztási cikkek jelentik, amelyek nem tekinthetók "létszü̈ségletnek", de még nem minösülnek elit fogyasztási cikkeknek sem (videomagnó, mikrohullámú sütó, mobiltelefon, hi-fi torony, számítógép). Ezeknél a cikkeknél a felsorolás arányában fokozatosan nỏ a két csoport közötti eltérés, mégpedig abban az értelemben, hogy a hozzáférők csoportjában 70-80\%-os a megjelenési arányuk, ezzel szemben a jelenleg még „kirekesztettek” körében a $80 \%$-os arány lépcsőzetesen lecsökken $40 \%$ körüli értékre ${ }^{12}$.

Megítélésünk szerint az általános társadalmi-demográfiai jellemzők tekintetében elvégzett csoportspecifikus elemzéssel nemcsak azt tudtuk bemutatni, hogy milyen a társadalmi helyzete annak a válaszadói körnek felmérésünkben, amely érintett, illetve jelenleg még (ön)kirekesztett a számítástechnikai lehetőségek alkalmazásában, hanem azokat a determináns jellemzöket is kiemeltük, amelyek a legjelentősebb strukturális eltérések hátterében húzódnak a hozzáférők és a kimarađók között. Így lokalizálhatjuk azokat a társadalmi csoportokat, akiket jelenleg még - nem érintettek meg az információs korszak lehetőségei a személyi számítógépek felhasználásában. A bemutatott adatok arra engednek következtetni, hogy a kulturális és a gazdasági erõforrásokkal való ellátottság, illetve a 
Barsi Boglárka - Csizmadia Zoltán: Egy nagyváros helyzete az információs társadalomban.

Tér és Társadalom, 15. 2001. 2. 147-172. $p$.

foglalkozási szerkezetben elfoglalt jelenlegi pozició jellemzöi alapvetöen eltérö lehetóségeket biztositanak a számitástechnikai eszközök és szolgáltatások társadalmi felhasználása, igénybevétele esetén.

Megfigyeléseink szerint a 18-59 éves györi lakosság esetén a számítástechnikai eszközök és szolgáltatások elérhetőségében és használatában jelentôsen jobb helyzetben vannak a magasabb iskolai végzettséggel rendelkezö személyek (föleg a diplomások), illetve a vezetöi, szakalkalmazotti, illetve a hivatali, ügyviteli munkakörben dolgozók, akiknél a munka jellegébỏl fakadóan nagyobb valószínűséggel jelenik meg a számitógép használat. A kedvezőbb kulturális és foglalkozásszerkezeti adottságok implikációiként az átlagosnál jobb anyagi helyzetü társadalmi csoportok jelenlẻte a fajsúlyosabb a hozzáférök csoportjában. Minél jobb $a z$ anyagi helyzete az adott háztartásnak, annál nagyobb a valószinüsége az otthoni és a munkahelyi hozzáférésnek. Ezzel szemben a,jelenleg még nem hozzáférök" csoportjára az jellemzö, hogy legfeljebb átlagos vagy az átlag alatti végzettségüek, jelentôs részük a foglakozási szerkezet kék szektorában dolgozik, fizikai munkakörben, az egy före jutó csalảdi havi nettó jövedelem legtöbbjüknél átlag alatti, és csak az alapvetö tartós fogyasztási cikkek piacán tudják felvenni a versenyt a magasabb társadalmi státuszú csoportok tagjaival. Komoly dilemmát jelent, hogy azoknál a foglalkoztatottaknál, akiknél hiányzik a „munkahelyi számítógép használat ösztönző ereje”, ahol nem jelent a munkaeröpiaci versenyben hátrányos pozíciót az ilyen irányú képzettség hiánya, öket miként lehet beintegrálni a folyamatosan bővuilö, generációs váltásokkal telítődő felhasználói körbe?

\section{Összegzés}

A számítástechnika, távközlés és a média konvergenciảjảnak eredményeként ma a következö évtizedekre jellemzö új társadalmi rend kibontakozásának vagyunk tanúi: az információs társadalomnak. E folyamat ma minden országban, régióban és településen kiemelkedö kérdéssé vált, cselekvési stratégiákra ösztönözve a társadalom szereplöit. A gyors fejlödés, az állandóan változó körülmények azonban állandó monitorozásra késztetnek.

A piac vagy az üzleti szféra egyedül nem képes hatékonyan megbirkózni olyan problémákkal, mint az „információ gazdagok” és az „információ szegények” között kialakuló üj társadalmi különbségek, az alacsony technológiai müveltség, a hozzáférés problémája vagy a képzett emberek hiányának kihívásai. Felmérésünk is világosan mutatja a társadalmi és térbeli szakadék kialakulásának lehetöségeit és veszélyeit. Nyilvánvaló, hogy ha az ország egyes területei vagy települései nem tudnak alkalmazkodni a társadalmi-gazdasági fejlödéshez, vagy nem tudnak megfelelni az információs társadalom kihívásainak, az egy új centrum-periféria kapcsolat kialakulásához vezethet. A szakadékok, töréspontok feltárása lehet a kiinduló pont az ilyen folyamatok elkeruléséhez. 
Barsi Boglárka - Csizmadia Zoltán: Egy nagyváros helyzete az információs társadalomban.

Tér és Társadalom, 15. 2001. 2. 147-172. p.

TÉT XV. évf. 2001 @ 2

Egy nagyváros helyzete...

\section{Jegyzetek}

${ }^{1}$ Györ Megyei Jogú Város megbízásából az MTA RKK Nyugat-magyarországi Tudományos Intézet helyzetelemzést készített „Az Intelligens Gyŏr Város stratégiai és operatív programja" címú tanulmányhoz.

${ }^{2}$ A csoportosítás a szolgáltatások engedély, illetve bejelentés szerinti terlileti kiterjedését mutatja.

${ }^{3}$ Magyarországon jelenleg nem egyértelmú, hogy kit nevezünk informatikusnak. Ezért vizsgálatunkban a következö képzéseket vettük figyelembe: múszaki informatika, informatika, programozó matematikus, számítástechnika.

4 A megkérdezett személyek általános társadalmi jellemzőit jelen tanulmány keretei között nem elemezzük részletesen, de a 1 . táblázat első blokkja tartalmazza az elemzés során alkalmazott fúggetlen változókat és a teljes minta alapvetó demográfiai-társadalmi mutatóinak megoszlását (a gyakoriság és a százalékos megoszlás alapjân).

5 Az eredményt megerősíti a tartós fogyasztási cikkek kapcsán feltett kontrollkérdés is. Pontosan megegyezik a két adat, tehát a saját háztartásban számítógéppel rendelkezők száma a két kérdés során nem kủlönbőző̉tt egymástól.

${ }^{6}$ Természetesen a hozzáféröi kör valamivel bỏvebb, mivel ide olyan személyeket is besorolhatunk, akik ugyan otthon és a munkahelyứkơn nem érhetik el a számítástechnikai eszkőzőket, de kủlönbözö intézményi keretek kőzött, illetve a rokonok, barátok, szomszédok révén, ha szǘkséges, hozzáférnek számítógéphez.

${ }^{7}$ A negyvenes éveikben járó személyek magas részvétele a hozzáférök csoportjában elöre vetíti a munkaviszonyhoz és a foglalkozás jellegéhez kapcsolódó feltételezést, miszerint a munkaviszony jellege és a foglalkozás típusa alapvetően meghatározza a hozzáférési arányokat.

${ }^{8}$ Szakmunkásképzö: 78,2\%; szakkőzépiskola: 43,7\%; gimnázium: 32,9\%; föiskola: 23,5\%; egyetem: $17,4 \%$.

${ }^{9}$ A két változó korrelációja 0,49 a maximális 1-böl, ami olyan pozitív összefúggésre utal, amely alaposabb elemzést igényel.

${ }^{10} \mathrm{Az}$ ơnbevalláson alapuló jövedelmi adatok megoszlása annak ellenére, hogy megbízhatatlanabb mutató a gazdasági erőforrások esetén, érzékelteti a mobilizálható anyagi javak fontosságát az információs- és kommunikációs technológiák és szolgáltatások elérésében.

11 A hiányzó válaszok aránya ebben az esetben szinte minimális (1 személy nem válaszolt az 500 megkérdezettből), és a kapott eredmények jobban kifejezik a háztartás hosszabb távon formálơdó gazdasági erejét, fogyasztóképességét.

${ }^{12}$ Nem szabad figyelmen kívủil hagyni, hogy a kủlönbözö tulajdonjavak birtoklási aránya így is jóval magasabb az országos felmérésekben megszokott értékeknél, mivel teljes egészében hiányzik a vidéki populáció és a hatvan év feletti korosztály a felmérésböl.

\section{Irodalom}

Az információs és kommunikációs technológiai szektor Magyarországon. (2001) Budapest, Központi Statisztikai Hivatal.

Bell, D. (1973) The Coming of Post-Industrial Society. A Venture in Social Forecasting. London, Heineman.

Drucker, P. F. (1993) Post-Capitalist Society. New York, Harper Business.

Élb G.-Pintér R. (1999) Finnország, út az információs társadalomba. Budapest, Kossuth Kiadó.

Fodor I. (2000) Merre megy a világ gazdasága, merre mehetünk mi. - Glatz F. (szerk.) Az információs társadalom. Budapest, Magyar Tudományos Akadémia. 95-113. o.

Hirközlési Statisztikai évkönyv 1999. (2000) Budapest, Hírkőzlési Föfelúgyelet Piaci Monitoring Igazgatóság.

IVSZ Évkönyv. (2001) Budapest, Informatikai Vállalkozások Szövetsége. 
Barsi Boglárka - Csizmadia Zoltán: Egy nagyváros helyzete az információs társadalomban.

Tér és Társadalom, 15. 2001. 2. 147-172. p.

172 Barsi Boglárka-Csizmadia Zoltán

TÉT XV. évf. 2001

Körősné Mikis M. (2001) Az IKT innovatív iskolai gyakorlatának vizsgálata nemzetkozi kitekintésben. Új Pedagógiai Szemle. július-augusztus. 87-97. o.

Közcélú, nem koncesszióköteles, távközlési szolgáltatást nyrijtók jegyzéke. (2001) Budapest, Budapesti Hírkozlési Felugyelet.

Nagy Á. (1999) Informatikus leszel...s katona. Budapest, Országos Kőzoktatási Intézet. (http://www.oki.hu/cikk.asp?Kod=egyeb-nagy.html)

Nemzetközi tảvközlési régiók. (2001) Budapest, Hírkőzlési Főfelugyelet Piaci Monitoring Igazgatóság.

Nielsen, J.-Ramsay, M. (2000) WAP Usability Report. Fremont, Nielsen Group.

Pannon GSM Sajtóközlemények. (2001) Internet: http://www.pgsm. hu/ceginfo/sajto/01jun6 hu.html.

Stehr, N. (1994) Knowledge Societies. London, Sage.

Telecities Declaration of Manchester. (1998) Manchester, Telecities.

\section{THE POSITION OF A MUNICIPALITY IN THE INFORMATION SOCIETY BOGLÁRKA BARSI - ZOLTÁN CSIZMADIA}

Nowadays the key engines of the development processes are the information and communication technologies, which may become the biggest industrial sectors in the forthcoming decades. This process however effects the society enormously in Hungary as well, where we are in the transition period towards the information society. There is a sharp competition among the cities with county rank constituting the backbone of the Hungarian city network to gain new investors, new managerial and administrative functions. The information society means a new competition situation for Hungary and so for the city network. As a consequence of it, it is very important to examine the situation of Györ in comparison with the other cities with county rank, to get a more accurate picture of its position in the information society. 